\title{
Review \\ Antiviral Activities of Algal-Based Sulfated Polysaccharides
}

\author{
Jonathan Ardhianto Panggabean 1,2®D, Sya'ban Putra Adiguna 1,2® ${ }^{1}$, Siti Irma Rahmawati ${ }^{2}$, Peni Ahmadi ${ }^{2, *}$, \\ Elmi Nurhaidah Zainuddin ${ }^{3,4, *}$, Asep Bayu ${ }^{2, *}$ and Masteria Yunovilsa Putra ${ }^{2, *}$ (i)
}

1 Department of Chemistry, Faculty of Mathematics and Natural Sciences, Universitas Gadjah Mada, Bulaksumur, Yogyakarta 55281, Indonesia; jonathanpanggabean@mail.ugm.ac.id (J.A.P.); syaban.putra@mail.ugm.ac.id (S.P.A.)

2 Research Center for Biotechnology, Research Organization for Life Sciences, National Research and Innovation Agency (BRIN), Jalan Raya Jakarta-Bogor KM. 46, Cibinong 16911, Indonesia; siti.irma.rahmawati@brin.go.id

3 Faculty of Marine Science and Fisheries, Hasanuddin University, Makassar 90245, Indonesia

4 Center of Excellent for Development and Utilization of Seaweed, Hasanuddin University, Makassar 90245, Indonesia

* Correspondence: peni.ahmadi@brin.go.id (P.A.); elmi18id@yahoo.com (E.N.Z.); asep044@brin.go.id (A.B.); masteria.yunovilsa.putra@brin.go.id (M.Y.P.)

Citation: Panggabean, J.A.; Adiguna, S.P.; Rahmawati, S.I.; Ahmadi, P.; Zainuddin, E.N.; Bayu, A.; Putra, M.Y. Antiviral Activities of Algal-Based Sulfated Polysaccharides. Molecules 2022, 27, 1178. https:// doi.org/10.3390/molecules27041178

Academic Editors: Jean-Marc Sabatier and Jacques Fantini

Received: 31 December 2021

Accepted: 2 February 2022

Published: 9 February 2022

Publisher's Note: MDPI stays neutral with regard to jurisdictional claims in published maps and institutional affiliations.

Copyright: (C) 2022 by the authors. Licensee MDPI, Basel, Switzerland. This article is an open access article distributed under the terms and conditions of the Creative Commons Attribution (CC BY) license (https:// creativecommons.org/licenses/by/ $4.0 /)$.

\begin{abstract}
An antiviral agent is urgently needed based on the high probability of the emergence and re-emergence of future viral disease, highlighted by the recent global COVID-19 pandemic. The emergence may be seen in the discovery of the Alpha, Beta, Gamma, Delta, and recently discovered Omicron variants of SARS-CoV-2. The need for strategies besides testing and isolation, social distancing, and vaccine development is clear. One of the strategies includes searching for an antiviral agent that provides effective results without toxicity, which is well-presented by significant results for carrageenan nasal spray in providing efficacy against human coronavirus-infected patients. As the primary producer of sulfated polysaccharides, marine plants, including macro- and microalgae, offer versatility in culture, production, and post-isolation development in obtaining the needed antiviral agent. Therefore, this review will describe an attempt to highlight the search for practical and safe antiviral agents from algal-based sulfated polysaccharides and to unveil their features for future development.
\end{abstract}

Keywords: sulfated polysaccharides; macroalgae; microalgae; antiviral agents

\section{Introduction}

In early 2020, the World Health Organization announced COVID-19 as a pandemic caused by the alarming and severe damage of the virus's spread [1]. The virus is identified as a novel betacoronavirus, viz. severe acute respiratory syndrome coronavirus 2 (SARS-CoV-2), which was first identified in China in late 2019 [2,3]. The emergence of a few new variants-including the Alpha variant in the United Kingdom (B.1.1.7), the Beta variant (B.1.351) in South Africa [4], the Gamma variant in Japan and Brazil (B.1.1.28.1), and the Delta variant (B.1.617.2) in India [5], as well as the newly discovered Omicron variant in South Africa (B.1.1.529) [6] - has motivated many efforts to treat and prevent the disease from further casualties. The emerging variants have highlighted the high probability of the emergence or re-emergence of viral infection and test our readiness to fight against them and future unknown pathogens [7]. The readiness may be underlined by a broad research base, including a race to obtain antiviral agents from natural sources.

Recently, sulfated polysaccharides have attracted much interest due to their potential antiviral activities against various strains through various mechanisms of action. They are reported to be active against herpes simplex virus 1 and 2 (HSV-1 and 2) [8,9], dengue virus 2 (DENV-2) [10], a wide range of human rhinovirus (HRV) strains [11], and the H1N1 influenza virus (PR8) or H3N2 [12], human immunodeficiency virus (HIV) [13], DNA damage induced by human papillomavirus (HPV) [14], respiratory syncytial virus (RSV) 
types A and B [15], viral hemorrhagic septicemia virus (VHSV) of salmonid fish, African swine fever virus (ASFV) [16], and the Varicella zoster virus (VZV) [17]. Recently, sulfated polysaccharides isolated from macroalgae (seaweeds) (i.e., l-carrageenan) showed antiviral activity against SARS-CoV-2 from an in vitro assay [18] in a promising (but limited) clinical trial [19].

Polysaccharides embedded with sulfate groups are known for their utilization in the foods, nutraceuticals, and cosmeceuticals industry as antioxidant, anticoagulant, and cholesterol-lowering agents [20,21]. These macromolecules can be obtained from marine algae and several bacteria, but they are not found in terrestrial plants [22]. The former source has attracted much attention since algae have a fast growth rate, produce multiple valuable chemicals, and act as natural $\mathrm{CO}_{2}$ sequesters. Owing to these characteristics, their utilization is attractive, as is their integration with other valuable chemicals in reducing $\mathrm{CO}_{2}$. Furthermore, sulfated polysaccharides derived from algae are obtained in relatively large quantities, with up to a $76 \%$ yield, and their extraction process can be performed by simple extractions [23]. In addition, algal-based sulfated polysaccharides are generally safe because many of them have been utilized in the foods and cosmeceuticals industry. Some of them have been recognized by the US Food and Drug Administration to be utilized for human consumption.

This review will highlight the opportunity to further explore the utilization of algalbased sulfated polysaccharides as producers of antiviral agents and will emphasize one of the strategies to overcome the future emergence or re-emergence of pathogens.

\section{Macroalgae and Microalgae: An Overview}

\subsection{Macroalgae}

Macroalgae or seaweeds are members of a broad group of algae with a distinctive macroscopic size. These colorful plants can be found in various aquatic climates, from polar to tropical marine environments. The apparent features on their photosynthetic pigment have led macroalgae to be categorized as green algae (Chlorophyta), red algae (Rhodophyta), and brown algae (Phaeophyta) [24]. The diversity of macroalgae has been known and utilized to benefit humans for many centuries. It has reached its development as an industry worth USD seven billion based on various geographical features of the marine environment from the coastline of Ireland to South East Asia. The practicality of macroalgae is clear from their industrial development as food sources and their ability to enhance other aspects of human life, from biofuel to medicine $[25,26]$.

Macroalgae contain low levels of lipids (0-3\%), medium amounts of protein (10-47\%), and up to $60 \%$ carbohydrates diversified among various species (Table 1) $[27,28]$. As one of the main constituents of macroalgae, the carbohydrate content has been extensively studied, both in terms of its utility and its production process, especially the content of sulfated polysaccharides such as ulvan from green algae, fucoidan from brown algae, and carrageenan from red algae [29]. Carrageenan is well-known for its utilization as an antioxidant and gelling agent in the cosmeceuticals industry, providing an enhanced consistency and texture [30]. On the other hand, fucoidan has been recognized for its bioactivities in enhancing the melanoma inhibition of lapatinib, anti-fibrotic effects, and anti-inflammatory and antioxidative effects [31,32]. In turn, like other sulfated polysaccharides, ulvan also exhibits the potential to induce intestinal cytokine production as an immunostimulatory agent and to protect liver damage due to oxidative stress [33,34]. 
Table 1. Chemical composition of various macroalgae containing sulfated polysaccharides.

\begin{tabular}{|c|c|c|c|c|c|}
\hline Algal Strain & Carbohydrate $(\%)$ & Protein (\%) & Lipid (\%) & Ash (\%) & Refs. \\
\hline \multicolumn{6}{|l|}{ Red Algae } \\
\hline Gracilaria birdiae & 73.01 & 8.03 & 0.46 & 6.05 & [35] \\
\hline Kappaphycus alvarezzi & 27.4 & 16.24 & 0.74 & 19.7 & [36] \\
\hline Mastocarpus stellatus & 35.08 & 9.14 & 4.63 & & [37] \\
\hline Porphyra tenera & 46.0 & n.d. ${ }^{1}$ & & & [18] \\
\hline Gelidium amansii $^{2}$ & $79.24-86.78$ & $2.22-3.46$ & & & [38] \\
\hline \multicolumn{6}{|l|}{ Brown Algae } \\
\hline Durvillaea antarctica & 54.57 & 10.79 & 0.43 & 26.06 & \multirow{3}{*}{ [39] } \\
\hline Macrocystis pyrifera & 52.71 & 9.81 & 0.21 & 30.47 & \\
\hline Lessonia nigrescens & 48.36 & 9.88 & 0.23 & 33.03 & \\
\hline Sargassum thunbergii & 37.00 & 7.14 & 7.88 & & [37] \\
\hline Laminaria japonica & 54.6 & 8.7 & & & \multirow{4}{*}{ [18] } \\
\hline Hizikia fusiforme & 94.4 & 10.9 & & & \\
\hline Sargassum horneri & 99.1 & 4.0 & & & \\
\hline Undaria pinnatifida & 60.3 & 2.6 & & & \\
\hline Fucus vesiculosus & & 12.99 & 3.75 & 20.71 & {$[40]$} \\
\hline \multicolumn{6}{|l|}{ Green Algae } \\
\hline Ulva sp. & 55.40 & 4.24 & 6.67 & & [37] \\
\hline Codium fragile & 29.0 & 1.4 & & & [18] \\
\hline Caulerpa veravelensis & 37.23 & 7.77 & 2.80 & 33.70 & \\
\hline Caulerpa scalpelliformis & 38.84 & 10.50 & 3.06 & 40.77 & [41] \\
\hline Caulerpa racemosa & 48.95 & 12.88 & 2.64 & 24.20 & \\
\hline
\end{tabular}

1 n.d. = not detected; ${ }^{2}$ The value range represented on the Gelidium amansii was taken from three different locations.

The production aspects also brought extensive attention to the recent development of providing valuable products embedded on macroalgae. Recently, Bahari and colleagues conducted an alkali-free extraction of carrageenan, resulting in the linear correlation between a carrageenan-rich precipitation yield and the combination of the temperature-time parameter. Despite the need to further study the exact composition of precipitated solids, these findings suggest that a more environmentally feasible extraction process can be developed [42]. On the broader scale of macroalgae, the production of nutritional composition is affected by the seasonal factor, seawater temperature, nutrient availability, salinity, and light exposure [39].The seasonal factor has been described by Mansilla and colleagues, who showed a negative correlation between the protein and carbohydrates composition of a brown alga extract, Macrocystis pyrifera. The highest carbohydrate content obtained from the winter and spring seasonal analysis was associated with the highest amount of protein [43]. This finding was also reported by Garcia-Vaquero and colleagues, who found a negative correlation between the protein and carbohydrate content and a positive correlation between light exposure and the production of antioxidant compounds during periods of increased oxidative stress damage in the summer and spring [44].

\subsection{Microalgae}

On the other hand, microalgae have a distinctive micro-scale cell size but possess the same ability to perform a photosynthetic process, which is commonly perceived to include "blue-green algae" (i.e., cyanobacteria). In comparison to macroalgae, microalgae have been harvested and utilized on a large scale to produce fatty acids, such as docosahexaenoic acid (DHA), and feed for aquacultures owing to their potential protein content [45,46]. This unicellular organism is well-known for its high protein composition, which relies on various aspects of cultivation and species (Table 2) [47]. Cultivation conditions, such as $\mathrm{pH}$ and salinity, alter growth rates alongside the protein, carbohydrate, and lipid content [48]. The nitrogen concentration in the culture medium also induces the production of protein, 
and the combination of high nitrogen and low temperatures has been found to increase the content of $\omega-3$ fatty acids, such as $\alpha$-linolenic acid (ALA) and docosahexaenoic acid (DHA) [49]. The carbohydrate content of microalgae has also been studied as one of the parameters of culture optimization; however, its bioactivities require further attention. Recently, Kumaran and colleagues optimized the culture condition for Nannochloropsis oceanica, resulting in an almost $45 \%$ increase in the carbohydrate content, which may provide insights into the up-scalability of production [50,51].

Table 2. Chemical composition of various microalgae containing sulfated polysaccharides.

\begin{tabular}{|c|c|c|c|c|c|}
\hline Algal Strain & Carbohydrate (\%) & Protein $(\%)$ & Lipid (\%) & Ash (\%) & Refs. \\
\hline \multicolumn{6}{|l|}{ Rhodophyta } \\
\hline \multirow{2}{*}{$\begin{array}{c}\text { Porphyridium cruentum } \\
\text { Porphyridium } \\
\text { purpureum }\end{array}$} & 42.17 & 19.57 & 5.69 & 23.59 & {$[52]$} \\
\hline & 43.88 & 15.08 & 1.73 & 18.57 & [53] \\
\hline \multicolumn{6}{|l|}{ Haptophyta } \\
\hline Isochrysis galbana & 17.67 & 28.98 & 31.09 & 15.16 & [52] \\
\hline Ruttnera lamellosa & 63.69 & 8.81 & 2.68 & 43.69 & [53] \\
\hline \multicolumn{6}{|l|}{ Cyanobacteria } \\
\hline Spirulina platensis & 13.60 & 56.79 & 8.33 & 10.05 & [54] \\
\hline \multicolumn{6}{|l|}{ Chlorophyta } \\
\hline Tetraselmis suecica & 24.01 & 26.05 & 14.68 & 17.99 & [52] \\
\hline Chlorella protothecoides & 31.6 & 48.2 & 6.9 & & [55] \\
\hline Chlorella vulgaris & $0.47^{*}$ & 0.90 * & $0.36 *$ & & [54] \\
\hline \multicolumn{6}{|c|}{ Bacillariophyceae (Diatom) } \\
\hline $\begin{array}{l}\text { Phaeodactylum } \\
\text { tricornutum }\end{array}$ & 16.91 & 26.95 & 12.73 & 27.95 & [52] \\
\hline \multicolumn{6}{|l|}{ Eustigmatophytes } \\
\hline $\begin{array}{c}\text { Nannochloropsis } \\
\text { oceanica } \\
\text { (post-optimization) } \\
\text { Nannochloropsis }\end{array}$ & $1.0 *$ & $7.58 *$ & $18.25 *$ & & [50] \\
\hline $\begin{array}{c}\text { oceanica } \\
\text { (pre-optimization) }\end{array}$ & $0.69 *$ & $6.40 *$ & $16.43 *$ & & \\
\hline $\begin{array}{c}\text { Nannochloropsis } \\
\text { gaditana }\end{array}$ & 15.90 & 33.17 & 27.89 & 11.52 & [52] \\
\hline
\end{tabular}

In summary of the above discussion on the proximate content of macroalgae and microalgae, carbohydrates are in the lead among other main constituents compared to the protein, fat, and ash content. The carbohydrate content, including polysaccharides, from marine algae correlates with the presence of sulfated polysaccharides. A study on Gymnogongrus torulosus polysaccharides extraction shows that, of the total polysaccharide content obtained, $35.6 \%$ is of the carrageenan type [56]. This study is supported by another study on Gymnogongrus tenuis, which was reported to provide $90 \%$ of the carrageenan type from the total polysaccharide obtained [57]. The study on galactans from Kappaphycus alvarezii also found a major constituent of $\kappa$ - and $\mu$-carrageenan ( $74 \%$ and $\sim 3 \%$, respectively) from the total obtained polysaccharide. This study also includes the possibility of finding an agaran-type sulfated DL-hybrid of galactans at a significant level ( $14 \%)$ from the total extract [58]. These studies indicate the potential to obtain sulfated polysaccharides as a member of carbohydrates due to their abundancy and potent biological activities. 


\section{Algal-Based Sulfated Polysaccharides}

Sulfated polysaccharides are a diverse group of anionic polymers. In algae, these macromolecules have critical supportive and protective functions for the cell walls of algae, thus promoting the high ionic strength of marine environments, pathogens, and moisture control [22]. These features allow them to carry out various biological activities, including antiviral activities.

\subsection{Carrageenan}

Carrageenan is commonly extracted from the various genus of red macroalgae, such as Chondrus, Eucheuma, Gigartina, and Hypnea. Its first isolation was extracted from Chondrus crispus or Irish moss [59,60]. It is isolated through the hot alkaline extraction of the biomass. Its structure contains repeating galactose and 3,6-anhydrogalactose units linked by alternating $\alpha-1-3$ and $\beta-1-4$ glycosidic linkages [61]. In general, carrageenan is categorized into various common types: $K$-(kappa), $\mathrm{t}$-(iota), $\mathrm{t}-(\mathrm{lambda}), \mu-(\mathrm{mu})$, and $v-(n u)$ carrageenan. The first three types are characterized according to their inclusion of one, two, and three sulfate ester groups on each dimer, respectively (Figure 1) [62]. The other types ( $\mu$ - and $\nu$-carrageenan) are considered as precursors of $\mathrm{k}$ - or $\mathrm{L}$-carrageenan through the formation of a 3,6-anhydrogalactose bridge under alkaline conditions [63]. Alkaline extraction provides a crude carrageenan, which requires a refining process to obtain high-quality carrageenan. The purification process involves a few techniques, such as freeze-thawing, which includes the gelation of crude extract prior to freeze-drying and alcohol precipitation using 2-propanol or another alcohol. The selection of this process depends on the relationship between the physical properties embedded and the chemical structure of the carrageenans. Freeze-thawing is used to obtain k-carrageenan, whereas เ- and $\lambda$-carrageenan powder are attained via alcohol precipitation [21].
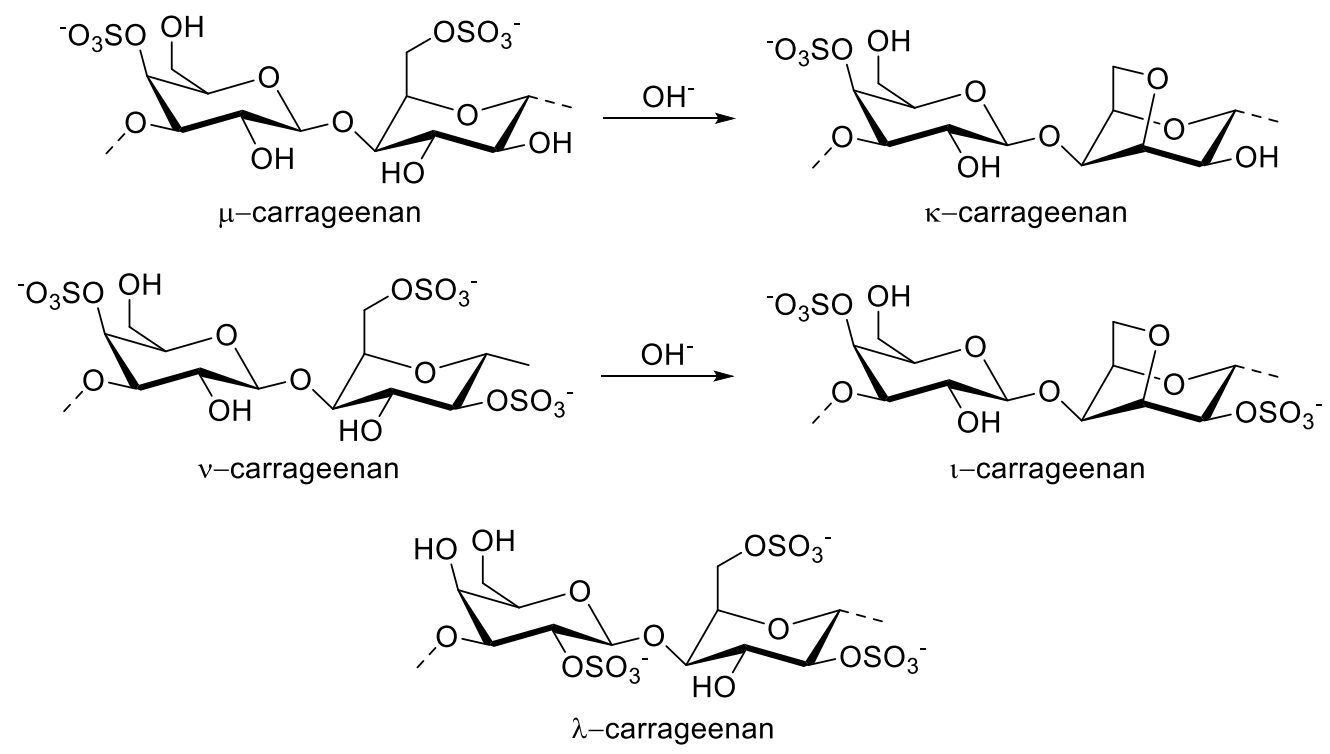

Figure 1. Chemical structure of $\mu-, k_{-}, v_{-}, l_{-}$, and $\lambda$-carrageenan with the transformation of carrageenan precursors into $\mathrm{K}$ - and $\mathrm{l}$-carrageenan under alkaline conditions.

Carrageenan is hydro-soluble, but its solubility depends on the amount of the ester sulfate group within the structures. $\lambda$-carrageenan is the most soluble species in water, followed by $\mathrm{l}$ - and $\mathrm{k}$-carrageenan. Due to the presence of ester sulfate, the solubility of carrageenan can be altered by the presence of cations. Sodium salts of $\mathrm{l}$ - and $\mathrm{k}$-carrageenan can improve their solubility in cold water. Meanwhile, the potassium salts of $\mathrm{t}$ and k-carrageenan are soluble only in hot water [64]. Moreover, the addition of potassium ions can produce carrageenan aerogels with different porosities, including meso- and microporous, which can be tuned and utilized in extended-release drug applications. 
Furthermore, carrageenan generally has a viscosity of more than $5 \mathrm{cPs}$ at $75{ }^{\circ} \mathrm{C}$ for a $1.5 \%$ solution, which decreases below a pH of 4.3 and lowers the gel strength by $20-25 \%$ for each $10{ }^{\circ} \mathrm{C}$ increase in the process temperature and for each $0.5 \mathrm{pH}$ unit decrease [65].

\subsection{Agaran}

Similar to carrageenan, agarans are a polysaccharide that can be found on algae. They have a similar structure as carrageenan with broader functional groups, such as sulfate, methyl, or pyruvate, instead of the exclusive sulfated polysaccharides [66]. In contrast with carrageenan, agarans are commonly found in two fractions (agarose and agaropection), which are different regarding their ionic charges, where the neutral fraction of agar (known as agarose and agaropectin) serves as the charged fraction. Agarans may be identified by ${ }^{13}$ C-NMR spectroscopy to allow L-galactose to be identified as the main constituent [62]. However, this identification may be affected if both polysaccharides exist in a hybrid form, as isolated by Zuniga and colleagues from Schizymenia binderi, who showed the unique position of the sulfate attachment located on the $O-3$ position of $\alpha$-L-galactopyranosyl, as well as the glycosylated $O-2$ position [67]. Despite the existence of this hybrid form, the agaran may be found as a significant component in room temperature water-extracted macroalgae Gymnogongrus tenuis, accounting for slightly more than $60 \%$ of its composition (Figure 2) [57]. Agaran can be extracted via hot water extraction above their gel melting points $\left(\sim 85^{\circ} \mathrm{C}\right)$. It is used as a gelling agent in food industries, as the gel maintains its stability and viscosity within a wide $\mathrm{pH}$ range of 4.5 to $9.0[64,68]$.

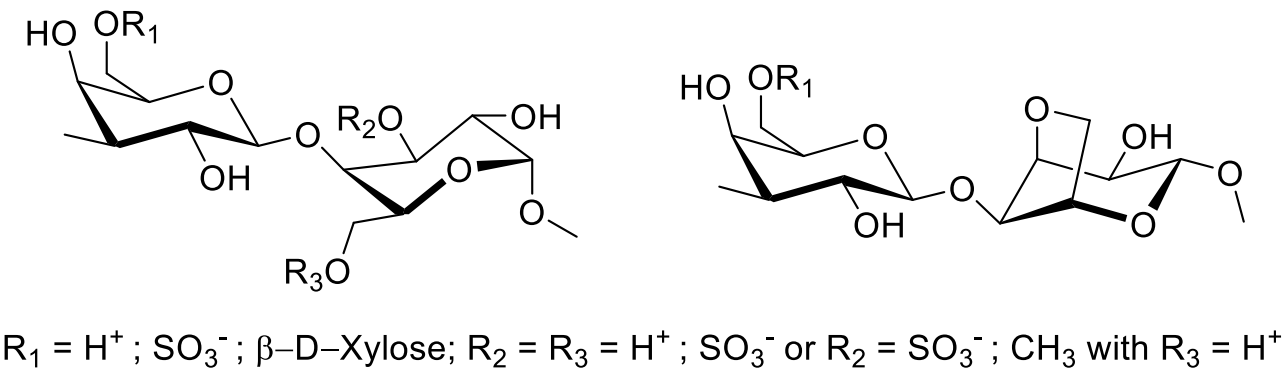

Figure 2. Chemical structure of agaran from Gymnogongrus tenuis [57].

\subsection{Fucoidan}

Fucoidan is a sulfated polysaccharide constituent of brown macroalgae with fucopyranose as one of its building blocks. It is typically obtained from brown macroalgae genera of Fucus, with up to a $62 \%$ yield. It is a water-soluble polysaccharide with a backbone consisting of $\alpha-(1 \rightarrow 3)$-linked L-fucopyranose or an alternating pattern of L-fucopyranosyls linked at the $\alpha-(1 \rightarrow 3)$ or $\alpha-(1 \rightarrow 4)$ position (Figure 3$)$. Different substituents could also be attached to the fucoidans' backbone (e.g., acetate, sulfate, or other glycosyl units) $[69,70]$. The wide variety of these substituents makes it difficult to extract fucoidan to obtain highquality fucoidan due to a few challenges. Separation could be carried out by utilizing the sulfate or other anionic properties of the fucoidans' substituent. For instance, these anionic groups could be exchanged with the negative ions contained in anionic resins, and the impurities could be eluted by an appropriate solvent, such as sodium chloride [71]. Another approach for the fucoidans' purification is shown by Zayed and colleagues, who utilized and immobilized a polycationic perylene diimide derivative to obtain a high-quality grade fucoidan with $97 \%$ purity [72]. 


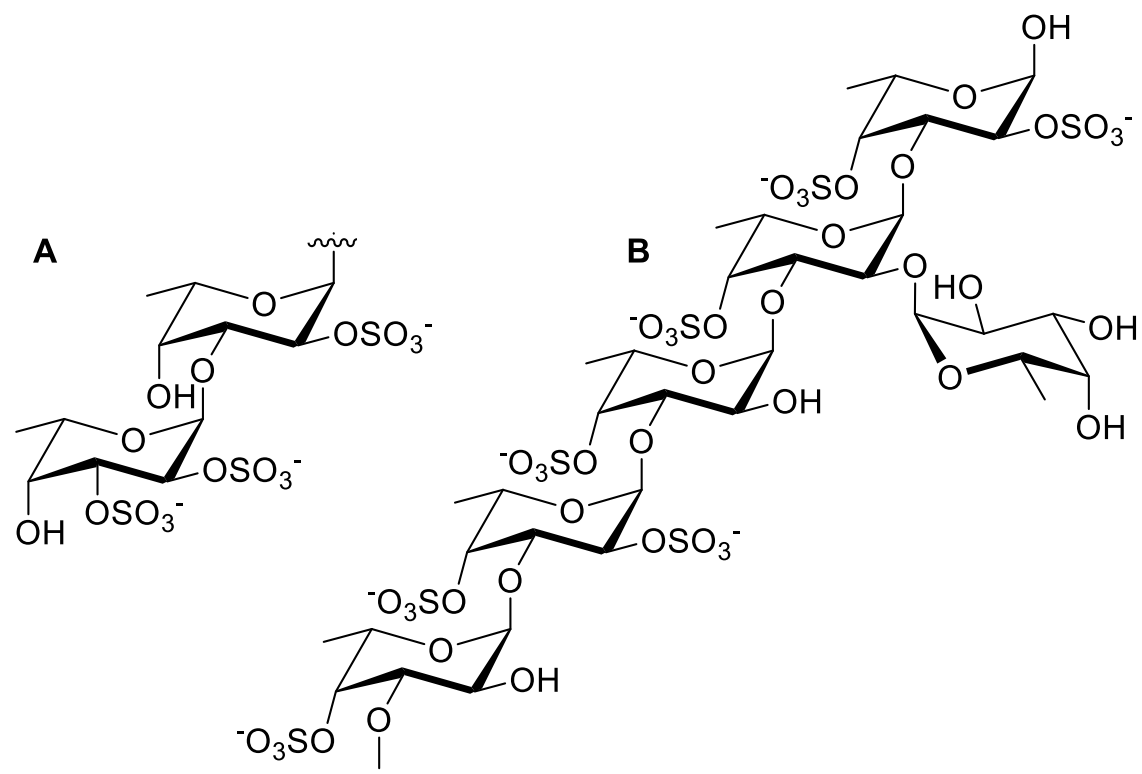

Figure 3. Chemical structure of the fucoidan from (A) Fucus vesiculosus and Ascophyllum nodosum and (B) Laminaria saccharina [70].

\subsection{Porphyran}

Porphyran comes from a specific genus of red macroalga of Porphyra. These polysaccharides' backbone consists of alternating 1,4-linked $\alpha$-L-galactosyl-6-sulfate and 1,3-linked $\beta$-D-galactosyl units, with a small number of 3,6-anhydro- $\alpha$-L-galactosyl units (Figure 4). A variation, however, can occur in the backbone (indicated by the methylation on the D-galactosyl units at the C-6 position) due to the extraction of Porphyra capensis [73,74]. Porphyran may also be obtained from a discolored "nori" P. yezoensis. Isaka and colleagues studied the discolored nori as an alternative porphyran source; the best result was $20.6 \mathrm{~g}$ of porphyrin per $100 \mathrm{~g}$ (compared to $10.6 \mathrm{~g}$ per $100 \mathrm{~g}$ of normal nori using ethanol maceration and heat treatment) [75]. Due to its high solubility in water, porphyran is commonly extracted by a conventional water maceration method that utilizes mechanical stirring at room temperature. However, applying physical forces, such as microwave-assisted extraction (MAE), resulted in a 191\% increase in yield with the conserved functional group of the polysaccharide (from $1.72 \%$ using traditional hot water extraction to $5.01 \%$ using MAE) [76].
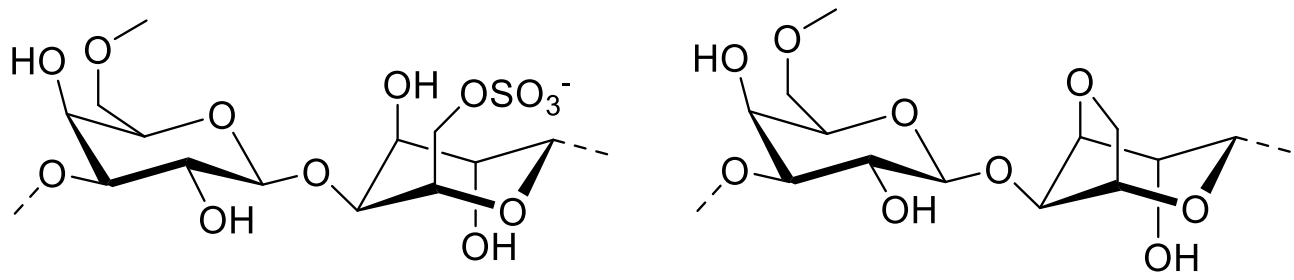

Figure 4. Chemical structure of the typical porphyran.

\subsection{Ulvan}

Ulvan is a type of sulfated polysaccharide commonly found in the genus Ulva. The backbone of ulvan consists of the repeating of a disaccharide unit, namely, ulvanobioronic acid, which has two types (type $A$ and type B), and ulvanobioses as the member of type $U$ (Figure 5). Type A ulvan contains $(1,4)$ linked $\beta$-D-glucuronic acid with $\alpha$-L-rhamnose 3sulfate, whereas type B can replace $\beta$-D-glucuronic acid with $\alpha$-L-iduronic acid. Type $U$, on the other hand, has $\beta$-D-xylose $(1,4)$ linked with the main $\alpha$-L-rhamnose 3 -sulfate $[77,78]$. Ulvan may be isolated through extraction via a salt removal process followed by acid 
extraction using $\mathrm{HCl}$. This acidic process is deemed superior to sodium oxalate extraction, owing to its higher yield $(8.2 \%$ vs. $4.0 \%)$. In addition, the acid extraction method provides selective extraction products with fewer proteins $(0.4-0.7 \%)$ than sodium oxalate $(4.1-5.9 \%)$ [79], which indicates the significant impact of $\mathrm{pH}$ on the extraction of ulvan.

Type A

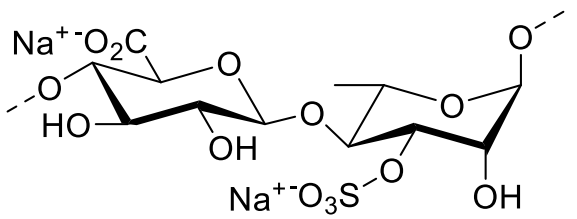

glucuronic acid and rhamnose-3-sulfate

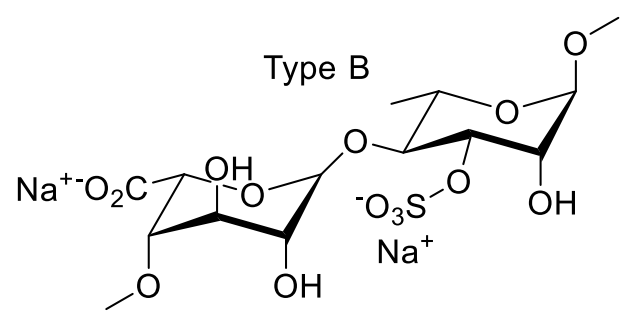

iduronic acid and rhamnose-3-sulfate

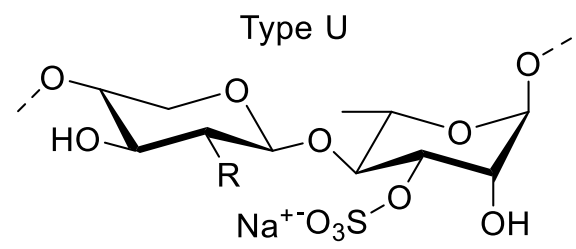

xylose or xylose 2-sulfate (R: $\mathrm{OH}$ or $\mathrm{OSO}_{3}{ }^{-}$) and rhamnose-3-sulfate

Figure 5. Chemical structure of a typical ulvan [78].

\subsection{Exopolysaccharides}

Exopolysaccharides are a specific type of polysaccharide defined as an extracellular polymeric substance. Exopolysaccharides are divided into two main groups: cell surfaceassociated exopolysaccharides, and those released into the surrounding environment. The association with the cell surface may be referred to as a sheath, which resembles a thin and dense layer in the surrounding cell, or capsules with layers of exopolysaccharides that resemble a cell shape. Another association with the cell surface is called slime; in this case, exopolysaccharides are dispersed around the organism without resembling a cell shape (Figure 6) [80]. The chemical composition of exopolysaccharides is diverse and different from other polysaccharides with sugar/monosaccharide members from the pentose, hexose, uronic acid, and amino sugar groups. Other constituents found on exopolysaccharides are non-sugar members, such as sulfuric acid and phosphoric acid (which are attached by ester linkages), acetic acid (which is attached by $O$-acyl linkages and $N$-linkages), succinic acid (which is attached by O-linkages), and pyruvic acid (which is attached by acetal linkages; Figure 7) [81]. Recently, Gaignard and colleagues screened 66 microalgae and cyanobacteria and found 17 new monosaccharides as a constituent of the secreted exopolysaccharides that are related to different phylogenetic affiliations [82]. 

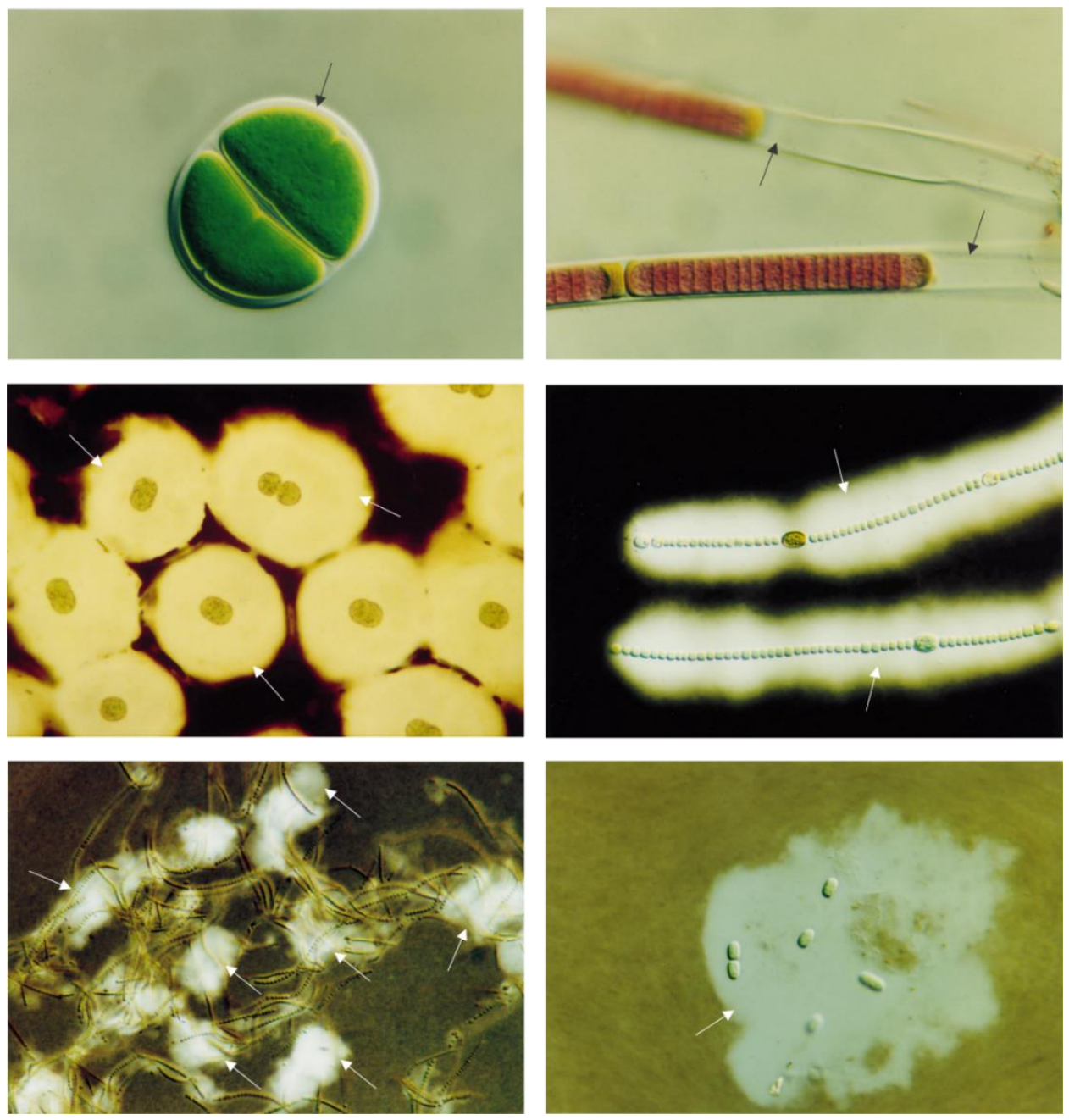

Figure 6. Types of exopolysaccharides (indicated by black and white arrows); top row-thin and dense layer named sheath structure (left-Chroococcus sp. $(1000 \times)$; right-Phormidium sp. $(1000 \times)$ ); middle row-the thick layer resembles a cell shape named capsules (left-Cyanothece CE 4 (775×); right-Nostoc sp. $(480 \times)$; bottom row - thick layer without cell shape resemblance named slime (left-Cyanothece PCC9224 (775×); right-Nostoc PCC7906 (194×). Reprinted from De Philippis, R.; Vincenzini, M. Exocellular polysaccharides from cyanobacteria and their possible applications. FEMS Microbiol. Rev. 1998, 22, 151-175, doi:10.1111/j.1574-6976.1998.tb00365.x, with permission from Elsevier.

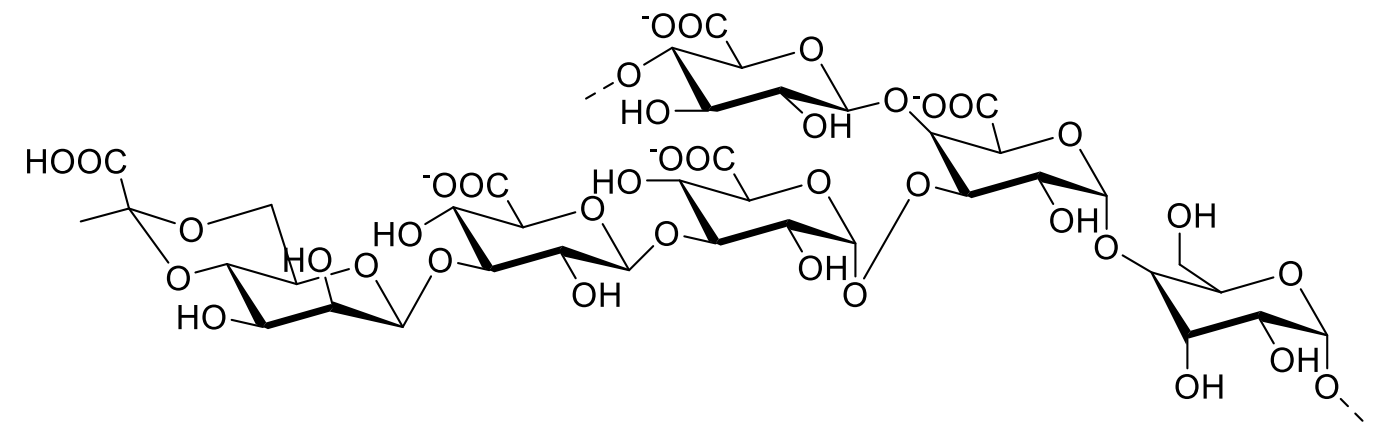

Figure 7. Monomeric unit of exopolysaccharides obtained from the Alteromonas macleodii subspecies fijiensis [81]. 


\section{Antiviral Activities of Algal-Based Sulfated Polysaccharides}

The wide variety of structural features and physical properties, along with the advancement of the downstream process in providing sulfated polysaccharides derived from algae, has been investigated in the study, which involves an assessment of their biological activities. A few algal-based sulfated polysaccharides are already well-known for their application as food additives and in the cosmeceutical industry by utilizing their antioxidative, anti-inflammatory, and anticoagulative properties, along with their potency to inhibit adipogenesis $[23,63,83]$. As a result of their multiple biological activities and their safety, they have gained attention as an antiviral agent [84-86]. In particular, such attention is driven by the urge to obtain a suitable agent to prevent further casualties of respiratory infection caused by the SARS-CoV-2 strain and to protect against new and re-emerging viruses [87]. Herein, we attempt to present the potential antiviral activities from sulfated polysaccharides and their relationship with the embedded physicochemical properties segregated by the respective active compound and summarized in Table 3.

\subsection{Carrageenan}

Carrageenan is a sulfated polysaccharide with remarkable attention on its potency as an inhibitor of respiratory virus. A study on $\mathrm{t}$-carrageenan revealed its superiority for inhibiting the HRV-infected HeLa cell line when compared to $\lambda$ - and $k$-carrageenan. It was found that $\mathrm{t-carrageenan}$ can completely block HRV2-induced cell death, but there is only a $55 \%$ cell protection for $\lambda$-carrageenan and $62 \%$ for $\mathrm{k}$-carrageenan. It has also shown the potency to inhibit the replication of various strains of HRV, HRV1, 14, 16, 83, and 84, with more than a $99 \%$ inhibition at $5 \mu \mathrm{g} / \mathrm{mL}$. In addition, the study emphasizes the safety of t-carrageenan, as no toxicity was observed against human nasal epithelial cells (HNep) at $>500 \mu \mathrm{g} / \mathrm{mL}$ and against the HeLa cell line at $>1000 \mathrm{ug} / \mathrm{mL}$ (Table 3) [11].

A recent study by Morokutti-Kurz et al. revealed that t-carrageenan inhibited the cell entry of SARS-CoV-2 pseudotyped lentivirus in a dose-dependent manner, with a virion particle neutralization value of $2.6 \mu \mathrm{g} / \mathrm{mL}$ of IC 50 (in ACE2-HEL293 cells/well infected with SARS-CoV-2 spike pseudotyped lentivirus). This finding confirmed that t-carrageenan interacted with the S glycoprotein of SARS-CoV-2 to inhibit viral infection (Figure 8). Interestingly, it had excellent activity in inhibiting $79 \%$ of the SARS-CoV-2 virus at $10 \mu \mathrm{g} / \mathrm{mL}$ compared to $\lambda$ - and $\mathrm{k}$-carrageenan, which showed an $80 \%$ inhibition activity at $100 \mu \mathrm{g} / \mathrm{mL}$. In addition, carrageenans did not show any toxicity in Vero B4 cells, as a $50 \%$ cell reduction survival was not reached at the highest tested concentration $(100 \mu \mathrm{g} / \mathrm{mL})$. This outcome indicates its safety for medical treatment (Table 3) [88]. In contrast, another study revealed that non-sulfated polysaccharides (carboxymethylcellulose and hydroxypropylmethylcellulose) and low-molecular-weight galactose-4-sulfate were inactive at $100 \mu \mathrm{g} / \mathrm{mL}$. Chondroitin sulfate, which contains one sulfate group on each dimer, also did not appear to significantly inhibit SARS-CoV-2 on Vero E6 cells [89]. These studies suggest that the activity might be related to the number of sulfate groups and the chain length of the observed polysaccharides. 


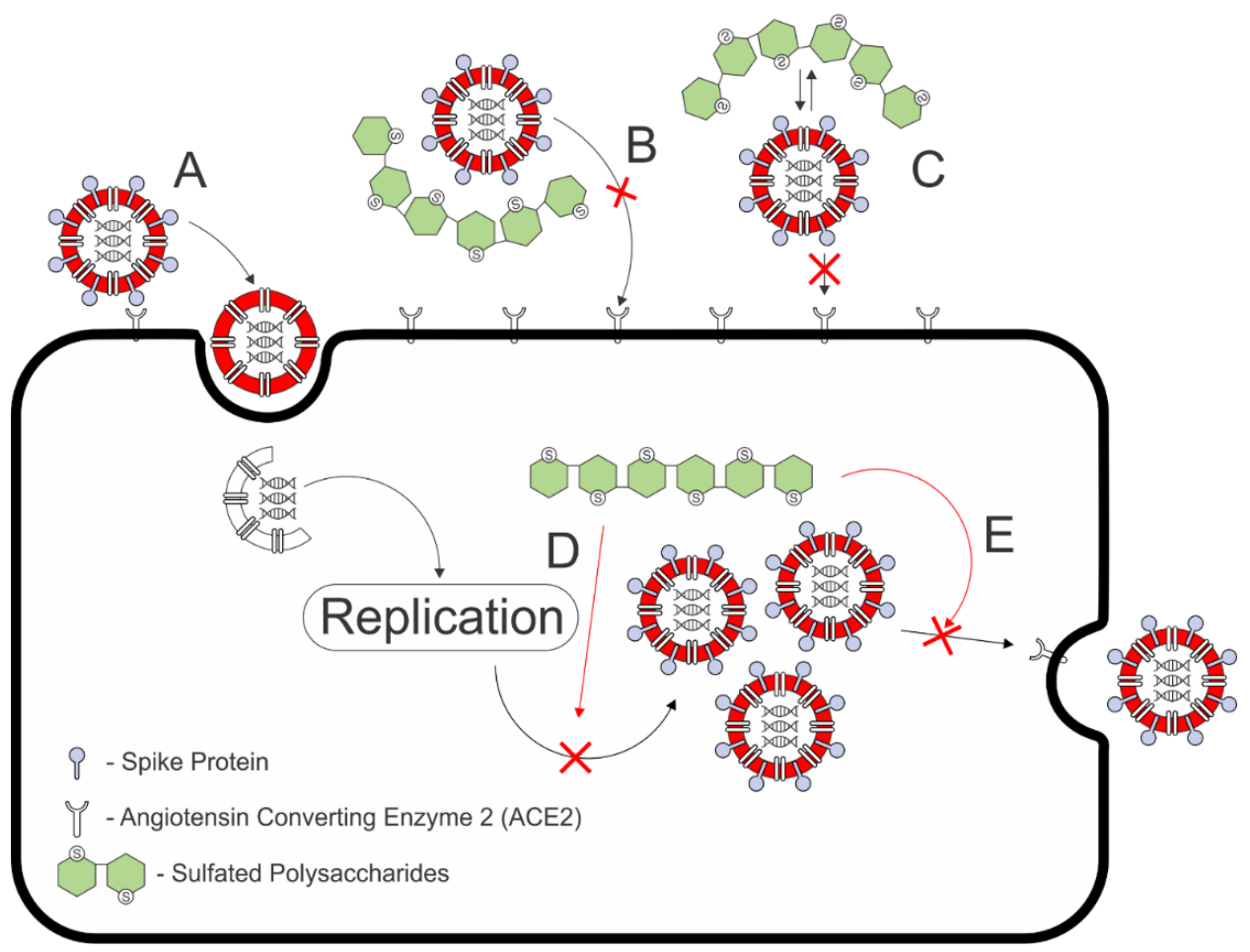

Figure 8. Proposed mechanism of action against viral infection on (A) the virion entry; $(\mathbf{B})$ inhibition of spike protein binding to ACE2 by complex formation of sulfated polysaccharides-ACE2, (C) ionic interaction between the negatively charged sulfate group and spike protein inhibit the formation of spike protein binding to ACE2, (D) sulfated polysaccharides inhibition on viral particle replication, indicated by the red arrow, (E) inhibition on neuraminidase to prevent assembled viral particle to be released, indicated by red arrow. Mechanisms B and C are proposed for the inhibition against SARS-CoV-2 by $[84,88,91]$. Mechanisms D and E are proposed from the finding on NDV by [92] and influenza A virus by [12]. Adapted from (Hans, et. al., 2021) and (Frediansyah, 2021).

Table 3. Summary of antiviral activity among carrageenans with each respective proposed mechanism of action and remarks on molecular weight and sulfate content of the tested compound.

\begin{tabular}{|c|c|c|c|c|c|c|}
\hline \multirow{2}{*}{$\begin{array}{l}\text { Sulfated } \\
\text { Polysaccharide }\end{array}$} & Virus Strain & Antiviral Activities & \multirow{2}{*}{ Proposed Mechanism of Action } & \multirow{2}{*}{$\begin{array}{l}\text { Toxicity } \\
\text { (Cell) }\end{array}$} & \multirow{2}{*}{$\begin{array}{l}\text { Remarks on Molecular Weight } \\
\text { and Sulfate Content }\end{array}$} & \multirow{2}{*}{ Refs. } \\
\hline & \multicolumn{2}{|c|}{ CP (\%) } & & & & \\
\hline \multirow[t]{2}{*}{$\begin{array}{l}\mathrm{\imath} \text {-Carrageenan } \\
\mathrm{K} \text {-Carrageenan } \\
\lambda \text {-Carrageenan }\end{array}$} & HRV2 & $\begin{array}{l}100 \%^{2} \\
62 \%^{2} \\
55 \%^{2}\end{array}$ & \multirow{3}{*}{$\begin{array}{l}\text { I-Carrageenan inhibits HRV2 entry to } \\
\text { infect HeLa cell line }\end{array}$} & \multirow{3}{*}{$\begin{array}{l}>1000 \mu \mathrm{g} / \mathrm{mL} \\
\underset{(\mathrm{HeLa})}{ }\end{array}$} & & \multirow{3}{*}{ [11] } \\
\hline & \multicolumn{2}{|c|}{$\log \mathrm{TCID}_{50} 1$} & & & & \\
\hline \multirow[t]{2}{*}{$\begin{array}{l}\mathrm{\imath} \text {-Carrageenan } \\
\mathrm{K} \text {-Carrageenan } \\
\lambda \text {-Carrageenan }\end{array}$} & HRV2 & $\begin{array}{l}<2^{2} \\
\sim 6^{2} \\
\sim 6^{2}\end{array}$ & & & & \\
\hline & \multicolumn{2}{|c|}{ Viral Replication Inh. at $5 \mu \mathrm{g} / \mathrm{mL}$} & & & & \\
\hline Ł-Carrageenan & $\begin{array}{l}\text { HRV1A } \\
\text { HRV14 } \\
\text { HRV16 } \\
\text { HRV83 } \\
\text { HRV84 }\end{array}$ & $\begin{array}{l}>99 \% \\
>99 \% \\
>99 \% \\
>99 \% \\
>99 \%\end{array}$ & $\begin{array}{l}\text { Reduces production of HRV particles on } \\
\text { HeLa cell line }\end{array}$ & $\begin{array}{c}>500 \mu \mathrm{g} / \mathrm{mL} \\
\quad \text { (HNep) }\end{array}$ & & [11] \\
\hline \multicolumn{7}{|c|}{ Neutralization Activity } \\
\hline $\begin{array}{l}\text { ¿Carrageenan } \\
\kappa \text {-Carrageenan } \\
\lambda \text {-Carrageenan }\end{array}$ & $\begin{array}{l}\text { SARS-CoV-2 Spike } \\
\text { pseudotyped lentivirus }\end{array}$ & $\begin{array}{l}79 \%^{3} \\
\sim 80 \%^{4} \\
\sim 80 \%^{4}\end{array}$ & $\begin{array}{l}\text { Inhibits cell entry of the SARS-CoV-2 } \\
\text { spike pseudotyped lentivirus }\end{array}$ & $\begin{array}{c}>100 \mu \mathrm{g} / \mathrm{mL} \\
(\text { Vero B4) }\end{array}$ & $\begin{array}{l}\text { 1. High molecular weight Fucoidan from } U \text {. pinnatifida and } F \text {. } \\
\text { vesiculosus shows less than } 50 \% \text { reduction in infection } \\
\text { 2. Polymer without sulfate found to be inactive }\end{array}$ & [88] \\
\hline \multicolumn{7}{|c|}{$\mathrm{EC}_{50}(\mu \mathrm{g} / \mathrm{mL})$} \\
\hline$\lambda$-Carrageenan & $\begin{array}{l}\text { SARS-CoV-2 } \\
\text { Influenza A (H1N1) } \\
\text { Influenza A (H3N2) } \\
\text { Influenza B }\end{array}$ & $\begin{array}{l}0.9 \\
0.3 \\
0.3 \\
1.4\end{array}$ & $\begin{array}{l}\text { 1. Neutralizing viral glycoprotein HA } \\
\text { 2. Blocking the VP harboring viral } \\
\text { ribonucleoprotein complexes }\end{array}$ & $\begin{array}{l}>300 \mu \mathrm{g} / \mathrm{mL} \\
\text { (MDCK) }\end{array}$ & $\begin{array}{l}\lambda \text {-carrageenan }(1025 \mathrm{kDa}) \text { shows better solubility in cold water } \\
\text { than other carrageenans because of its higher sulfate content }\end{array}$ & [90] \\
\hline
\end{tabular}

$\mathrm{CP}=$ cell protection; $\mathrm{HRV}=$ human rhinoviruses followed with each respective strain number; HeLa = human cervical epithelial carcinoma cell line; HNep = human nasal epithelial cells; Vero B4 = embryonic African green monkey kidney cells; HA = hemagglutinin; VP = viral particles; $\mathrm{MDCK}=$ Madin-Darby canine kidney cells; ${ }^{1}$ value of viral replication inhibition; ${ }^{2}$ at $200 \mu \mathrm{g} / \mathrm{mL}$ concentration; ${ }^{3}$ includes $2.6 \mu \mathrm{g} / \mathrm{mL} \mathrm{IC}{ }_{50}$ for t-carrageenan and percent neutralization obtained at $10 \mu \mathrm{g} / \mathrm{mL} ;{ }^{4}$ at $100 \mu \mathrm{g} / \mathrm{mL}$. 
Furthermore, Morokutti-Kurz et al. observed a low activity on fucoidan by only a $~ 50 \%$ inhibition (compared to $\mathrm{L}_{-}, \lambda$-, and $\mathrm{k}$-carrageenan by a $<40 \%$ inhibition) at $100 \mu \mathrm{g} / \mathrm{mL}$ [88]. Although $\lambda$ - and $\kappa$-carrageenan were active against SARS-CoV-2, the researchers observed a small fraction of t-carrageenan (27\% and $16 \%$ ) in two carrageenan samples based on NMR analysis. The possible responsibility of $\mathrm{l}$-carrageenan to enhance the activity of the two latter carrageenans should not be excluded. In the specific case of $\lambda$ - and $k$ carrageenan alone, Jang et al. confirmed the activity of $\lambda$-carrageenan against the virus entry of SARS-CoV-2, together with influenza A and B. Herein, $\lambda$-carrageenan with a molecular weight of $1025 \mathrm{kDa}$ had an $\mathrm{EC}_{50}$ of $0.9 \pm 1.1 \mu \mathrm{g} / \mathrm{mL}$ and a $\mathrm{CC}_{50}$ of $>300.0 \mu \mathrm{g} / \mathrm{mL}$ (selectivity index of $>333.3$ ) in the in vitro test of Vero cells infected with SARS-CoV-2, whereas remdesivir had an $\mathrm{EC}_{50}$ of $23.5 \pm 1.2 \mu \mathrm{M}(\sim 14.16 \mu \mathrm{g} / \mathrm{mL})$ and $\mathrm{CC}_{50}$ of $>300.0 \mu \mathrm{M}$ (selectivity index of $>12.8$ ) [90]. Moreover, its $\mathrm{EC}_{50}$ values against influenza $\mathrm{A}$ and $\mathrm{B}$ viruses were 0.3 to $1.4 \mu \mathrm{g} / \mathrm{mL}$, with no cytotoxicity up to $300 \mu \mathrm{g} / \mathrm{mL}$ (selectivity index >263.2). The contamination between carrageenan types might be a concern for the sole activity embedded on both the known potency and the selectivity of carrageenans involving a structural feature relationship with their bioactivities [93]. Regardless of the contrast and possible impurities, the study on tuning the potency of carrageenans by the information on the composition and structural feature, such as the molecular weight distribution, number of sulfate esters, and their position, together with bioactivities, could provide further interesting findings. This matter remains to be discovered.

\subsection{Fucoidan}

Owing to it being moderately active in inhibiting SARS-CoV-2 compared to sea cucumber sulfated polysaccharides, fucoidan has drawn considerable attention as a potential antiviral agent. A study on fucoidan isolated from Adenocystis utricularis showed that it inhibits HSV-1 and HSV-2 by 1.25 and $1.63 \mu \mathrm{g} / \mathrm{mL}$ of $\mathrm{IC}_{50}$, respectively. The $\mathrm{IC}_{50}$ value was also found following an amount of fucose by $84 \%-\mathrm{mol}$ of the extracted product compared with the lowest fucose content by $60 \%-m o l$ with $4.79 \mu \mathrm{g} / \mathrm{mL}$ and $8.46 \mu \mathrm{g} / \mathrm{mL}$ of $\mathrm{IC}_{50}$, respectively (Table 4) [94]. A further study conducted on fucoidan isolated from Undaria pinnatifida supported the finding related to the HSV-1 and HSV-2 inhibition potential by 2.5 and $2.6 \mu \mathrm{g} / \mathrm{mL} \mathrm{IC}_{50}$, respectively, with the addition of influenza A by $15 \mu \mathrm{g} / \mathrm{mL}$, where fucoidan was added at the same time as the viral infection. The mechanism of action is proposed by inhibiting virus-host cell-binding. The mechanisms were observed by the decrease in $\mathrm{IC}_{50}$ on the addition of fucoidan after $1 \mathrm{~h}$ of virus infection by 14,5.1, and $55 \mu \mathrm{g} / \mathrm{mL} \mathrm{IC}_{50}$ against HSV-1, HSV-2, and influenza A virus, respectively (Table 4) [95]. Furthermore, Song et al. reported that ı-carrageenan inhibited only 50-60\% SARS-CoV2 infection on Vero E6 Cells at $\geq 125 \mu \mathrm{g} / \mathrm{mL}$ [86,89]. Sulfated polysaccharides isolated from sea cucumber Stichopus japonicus (SCSP), which is mainly composed of fucosylated chondroitin sulfate and fucoidan, had an $\mathrm{IC}_{50}$ of $9.10 \mu \mathrm{g} / \mathrm{mL}$, and fucoidan itself inhibited $60 \%$ of viral infection at $\geq 15.6 \mu \mathrm{g} / \mathrm{mL}$. The study also noted that a high level of structural flexibility is required for the polysaccharide to bind to S glycoprotein. The flexibility is highlighted by the tighter binding between the sulfated glycosaminoglycan and envelope protein compared to the more rigid suramin [96]. The flexibility of sugar chains has been reported as one of the main features of polysaccharide solutions' confirmation, together with morphological characteristics and polysaccharide conformation. The presence of sulfates on a polysaccharide chain also improves the solubility and antioxidant activity by forming a more outstretched conformation than non-sulfated polysaccharides [97-99]. 
Table 4. Summary of antiviral activity among various fucoidan, with each respective proposed mechanism of action and remarks on molecular weight and sulfate content of the tested compound.

\begin{tabular}{|c|c|c|c|c|c|c|c|}
\hline Sulfated Polysaccharide & Virus Strain & Antivir & ctivities & $\begin{array}{l}\text { Proposed } \\
\text { Mechanism of } \\
\text { Action }\end{array}$ & $\begin{array}{l}\text { Toxicity } \\
\text { (Cell) }\end{array}$ & Remarks on Molecular Weight and Sulfate Content & Refs. \\
\hline \multirow[t]{2}{*}{$\begin{array}{c}\text { Fucoidan } \\
\text { (Adenocystis utricularis) }\end{array}$} & $\begin{array}{l}\text { HSV-1 } \\
\text { HSV-2 }\end{array}$ & \multicolumn{2}{|c|}{$\begin{array}{l}1.25 \mu \mathrm{g} / \mathrm{mL} \mathrm{IC}_{50} \\
1.63 \mu \mathrm{g} / \mathrm{mL} \mathrm{IC} 50\end{array}$} & & \multirow[t]{2}{*}{$>1000 \mu \mathrm{g} / \mathrm{mL}$ Vero ${ }^{1}$} & $\begin{array}{l}\text { 1. Lower molecular weight yields less antiviral activity } \\
\text { 2. Higher sulfate content yields greater antiviral activity }\end{array}$ & \multirow[t]{2}{*}{ [94] } \\
\hline & & $\begin{array}{l}\text { immediate } \\
\text { addition }{ }^{2}\end{array}$ & $\begin{array}{l}\text { addition after } \\
1 \text { h infection }\end{array}$ & & & & \\
\hline \multirow[t]{2}{*}{$\begin{array}{l}\text { Fucoidan (Undaria } \\
\text { pinnatifida) }\end{array}$} & $\begin{array}{c}\text { HSV-1 } \\
\text { HSV-2 } \\
\text { Influenza A }\end{array}$ & $\begin{array}{l}2.5 \mu \mathrm{g} / \mathrm{mL} \\
2.6 \mu \mathrm{g} / \mathrm{mL} \\
1.5 \mu \mathrm{g} / \mathrm{mL}\end{array}$ & $\begin{array}{l}14 \mu \mathrm{g} / \mathrm{mL} \\
5.1 \mu \mathrm{g} / \mathrm{mL} \\
55 \mu \mathrm{g} / \mathrm{mL}\end{array}$ & $\begin{array}{l}\text { Inhibition of viruses } \\
\text { into host cell }\end{array}$ & $\begin{array}{l}>2000 \mu \mathrm{g} / \mathrm{mL} \text { Vero cell } \\
>2000 \mu \mathrm{g} / \mathrm{mL} \text { Vero cell } \\
>2000 \mu \mathrm{g} / \mathrm{mL} \text { MDCK cell }\end{array}$ & & [95] \\
\hline & & $\begin{array}{l}\begin{array}{c}\text { plaque } \\
\text { formation } \\
\left(\mathrm{IC}_{50}\right)\end{array}\end{array}$ & $\begin{array}{c}\text { Influenza A } \\
\text { neu- } \\
\text { raminidase } \\
\left(\mathrm{IC}_{50}\right)\end{array}$ & & & & \\
\hline $\begin{array}{c}\text { Fucoidan } \\
\text { (Kjellmaniella crassifolia) }\end{array}$ & $\begin{array}{c}\text { Infl. A } \\
\text { (H1N1) } \\
\text { Infl. A } \\
\text { (H3N2) }\end{array}$ & $\begin{array}{l}30.5 \mu \mathrm{g} / \mathrm{mL} \\
6.3 \mu \mathrm{g} / \mathrm{mL}\end{array}$ & $8.8 \mu \mathrm{g} / \mathrm{mL}$ & $\begin{array}{l}\text { Inhibition of enzyme } \\
\text { related to virus } \\
\text { adsorption or release } \\
\text { process }\end{array}$ & $\sim 80 \%$ cell viability at $1000 \mu \mathrm{g} / \mathrm{mL}$ & $\begin{array}{l}30.1 \% \text { sulfate } \\
\text { content }\end{array}$ & [12] \\
\hline
\end{tabular}

HSV—herpes simplex virus; Infl. A—influenza A; MDCK—Madin-Darby canine kidney cells; ${ }^{1}$ Vero cell used is African green monkey kidney cells; ${ }^{2}$ values are presented by $\mathrm{IC}_{50}$ for each treatment.

Findings related to the influenza A virus were derived from the further assessment regarding fucoidan isolated from Kjellmaniella crassifolia, with exceptional results from other studies. The isolated sulfated polysaccharides were found to have inactivation capabilities after being utilized to pretreat a mouse-adapted H1N1 influenza virus (PR8) and H3N2 (a variant of the influenza A virus) by 30.5 and $6.3 \mu \mathrm{g} / \mathrm{mL}$ on the concentration required to inhibit the plaque number by $50 \%$. In addition to its inactivation properties, fucoidan inhibited the influenza A virus neuraminidase (Figure 8), an enzyme that promotes virion entry and the release of the influenza A virus by $8.8 \mu \mathrm{g} / \mathrm{mL}$ of $\mathrm{IC}_{50}$. The enzyme inhibition further supported in vivo evidence that fucoidan enhances the PR-8-infected mice's survival and decreases pulmonary virus titers [12]. Further support for the potency of fucoidan was obtained from a different perspective of the symptoms and remarked treatment of respiratory infection, with its potential to be produced as fucoidan preparation and act as a supplementary agent. This potential is indicated by reduced allergic asthma symptoms via airway inflammatory response attenuation and mucus hypersecretion. In addition, fucoidan can significantly inhibit inflammatory mediators associated with toll-like-receptor3 (TLR3) when a $1 \mathrm{mg} / \mathrm{mL}$ solution is prepared in vitro [100-102].

\subsection{Agaran}

For less sulfated polysaccharides, agaran might be accompanied by sulfate constituents, and a few studies have discussed its antiviral activities. A study on sulfated agarans isolated from Bostrychia montagnei revealed the antiviral activities against HSV-1 and HSV-2, with the active fraction belonging to the higher sulfate content ( $17 \%$ to $24 \%$ ) rather than to the lower sulfate content ( $11.2 \%$ to $16.2 \%)$. Active fractions can deactivate the other fraction by $\geq 50 \mu \mathrm{g} / \mathrm{mL}$ of $\mathrm{IC}_{50}$ to reduce plaque formation in Vero cells to a greater extent than the large range of $12.9-25.7 \mu \mathrm{g} / \mathrm{mL}$ of $\mathrm{IC}_{50}$ for HSV-1 and $11.2-46.2 \mu \mathrm{g} / \mathrm{mL}$ of $\mathrm{IC}_{50}$ for HSV-2 (Table 5) [103]. Further studies on the sulfated agaran isolated from Acanthophora spicifera yielded the same result, confirming that the dominance of the active fraction against HSV-1 and HSV-2 leads by the fraction with a higher amount of sulfate. These findings suggest the importance of the sulfate group attached to polysaccharide backbones in antiviral activity [104]. They also emphasize that additional valuable information regarding sulfate modification and its antiviral activities can be obtained. 
Table 5. Summary of antiviral activity among various agaran and ulvan, with each respective proposed mechanism of action and remarks on molecular weight and sulfate content of the tested compound.

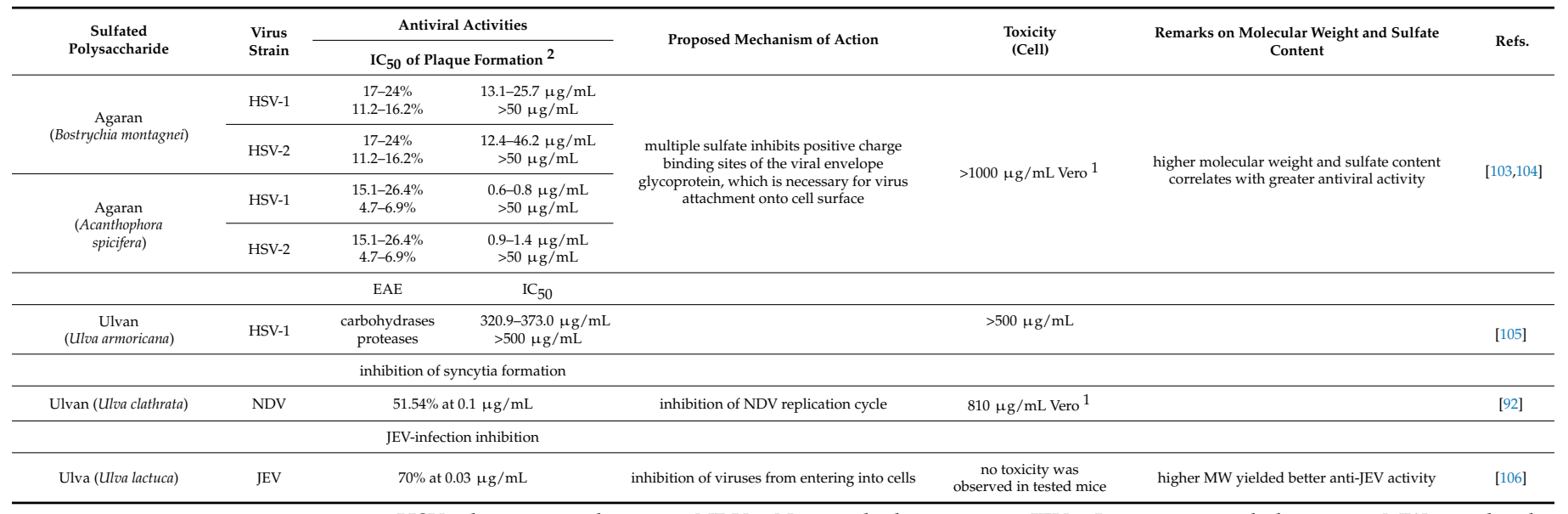

$\mathrm{HSV}=$ herpes simplex virus; NDV = Newcastle disease virus; JEV = Japanese encephalitis virus; $\mathrm{MW}=$ molecular weight; EAE = enzyme-assisted extraction. ${ }^{1}$ The Vero cell used is African green monkey kidney cells. ${ }^{2}$ The presented percentage values are the sulfate content range of the fractionated extract.

\subsection{Porphyran}

Porphyran has received little attention regarding its potential status as an antiviral agent. One study suggests that a dietary supplement of Porphyra umbilicalis, a member of the genus Porphyra known for producing porphyran, can increase hyperplastic epidermal lesions from 36 to 100\%, while also inhibiting DNA damage induced by human papillomavirus (HPV) on transgenic mice [14]. A porphyran derivative called oligoporphyran could also retain the potential to provide antiviral activities. It was found that these derivatives have a better antioxidant effect by $2.01 \mathrm{mg} / \mathrm{mL} \mathrm{IC}_{50}$ of scavenging effect in comparison with a higher molecular weight by $26 \%$ inhibition at $1.10 \mathrm{mg} / \mathrm{mL}$. In addition, an enhancement of immunomodulation is also indicated by degraded porphyran at $\sim 130 \mu \mathrm{mol} / \mathrm{L}$ of $\mathrm{NO}$ secretion in comparison to a positive control lipopolysaccharide and non-degraded porphyran ( 70 and $\sim 100 \mu \mathrm{mol} / \mathrm{L}$, respectively) $[74,107,108]$.

\subsection{Ulvan}

The bioactivity potential exhibited by ulvan regarding antiviral activities against HSV-1 with 373.0 and $320.9 \mu \mathrm{g} / \mathrm{mL} \mathrm{EC}_{50}$ were found from the enzyme-assisted extraction (EAE), with a multiple-mix of glycosyl hydrolases and exo- $\beta-1,3(4)$-glucanase of Ulva armoricana, respectively (Table 5). The enzyme-assisted extraction also revealed that the product of EAE from the group of carbohydrases is superior to the protease enzyme in terms of antiviral activity against HSV-1 for the inactivity $\left(>500 \mu \mathrm{g} / \mathrm{mL} \mathrm{EC}_{50}\right)$ of the product. The difference among enzyme types used also correlates with an increase in rhamnose (the main component of ulvan) in the carbohydrase products. This further implies that the selective manner of the enzyme might enhance ulvan production [105]. A further assessment of the antiviral potential of ulvan is exhibited in one study that reported its ability to inhibit syncytia formation by $51.54 \%$ at $0.1 \mu \mathrm{g} / \mathrm{mL}$ without significant virucidal activity against Newcastle disease virus (NDV) virions while exhibiting a low cytotoxicity on Vero (African green monkey kidney) cells by $810 \mu \mathrm{g} / \mathrm{mL} \mathrm{IC}_{50}$. The lack of virucidal activity of the isolated ulvan from Ulva clathrate might correlate with the inhibition of the NDV replication cycle [92], which also contributes to the known mechanism of the action of sulfated polysaccharides (Figure 8).

As further evidence of ulvan's potential as an antiviral agent, it was found to inhibit Japanese encephalitis virus (JEV) infection in Vero cells by $70 \%$ in terms of cell viability compared to a control condition. A further examination of the extract from Ulva lactuca against JEV reveals the ulvan's ability to form complexes with JEV and, thus, to prevent 
JEV from entering cells. Other research cites the efficacy of Ulva lactuca extract in vivo, which shows a $40 \%$ survival rate among JEV-infected mice (there were no survivors in the control group) [106].

\subsection{Exopolysaccharides}

The large group of exopolysaccharides also contributes to the search for antiviral agents from algal-based sulfated polysaccharides. An early potency was found on the marine microalgae Cochlodinium polykrikoides. The isolated extracellular sulfated polysaccharides can have a cytopathic effect on influenza virus types $A$ and $B$, as well as respiratory syncytial virus (RSV) types A and B, and HIV-1. A further fractionation process showed inhibition against the mentioned strains from obtaining two fractions that exhibit different antiviral activities. Fraction A1 was found to inhibit only HSV-1 but not parainfluenza virus type 2; the other fraction, A2, was active in the opposite manner on the viral strain (Table 6), despite their similar monosaccharide composition and IR spectra analysis [15].

Table 6. Antiviral activities of various sources of exopolysaccharides.

\begin{tabular}{|c|c|c|c|}
\hline \multirow{3}{*}{ Virus Strain } & \multicolumn{3}{|c|}{ Exopolysaccharide Source } \\
\hline & \multicolumn{3}{|c|}{ C. polykrikoides } \\
\hline & \multicolumn{2}{|c|}{ Fraction A1 $(\mu \mathrm{g} / \mathrm{mL})$} & Fraction $\mathrm{A} 2(\mu \mathrm{g} / \mathrm{mL})$ \\
\hline Influenza A & \multicolumn{2}{|c|}{1.1} & 0.45 \\
\hline Influenza B & \multicolumn{2}{|c|}{8.3} & 7.1 \\
\hline RSV-A (Long) & \multicolumn{2}{|c|}{2.0} & 3.0 \\
\hline RSV-A (FM-58-8) & \multicolumn{2}{|c|}{3.0} & 2.3 \\
\hline RSV-B & \multicolumn{2}{|c|}{0.8} & 0.8 \\
\hline HIV-1 & \multicolumn{2}{|c|}{1.7} & 1.7 \\
\hline $\begin{array}{c}\text { Parainfluenza virus } \\
\text { type } 2\end{array}$ & \multicolumn{2}{|c|}{25.3} & 0.8 \\
\hline \multirow[t]{2}{*}{ HSV-1 } & \multicolumn{2}{|c|}{4.52} & 21.6 \\
\hline & \multicolumn{2}{|l|}{ Porphyridium sp. ${ }^{1}$} & R. reticulata ${ }^{1}$ \\
\hline HSV-1 & 1 & 100 & 10 \\
\hline HSV-2 & 5 & 200 & 20 \\
\hline \multirow[t]{2}{*}{ VZV } & 0.7 & 100 & 8 \\
\hline & \multicolumn{2}{|l|}{ P. cruentum } & Ellipsoidon sp. \\
\hline & $50-60 \%{ }^{2}$ & $<40 \%^{2}$ & $50-60 \%^{2}$ \\
\hline \multirow[t]{3}{*}{ ASFV } & $60-70 \%^{3}$ & $>100 \%^{3}$ & $40-50 \%^{3}$ \\
\hline & \multicolumn{3}{|c|}{ P. cruentum $\left(\mathrm{EC}_{50}\right.$ in $\left.\mu \mathrm{g} / \mathrm{mL}\right)$} \\
\hline & $\mathrm{MgSO}_{4}$ media 4 & $\mathrm{MgCl}_{2}$ media 4 & Control \\
\hline \multirow{4}{*}{$\begin{array}{c}\text { HSV-1 } \\
\text { HSV-2 } \\
\text { Vaccinia virus } \\
\text { Vesicular stomatitis } \\
\text { virus }\end{array}$} & 34 & 38 & 56 \\
\hline & 12 & 20 & 20 \\
\hline & 12 & 20 & 20 \\
\hline & 20 & 56 & 100 \\
\hline
\end{tabular}

${ }^{1}$ Values are presented as the cytopathic effect protection (CPE50) $(\mu \mathrm{g} / \mathrm{mL}) ;{ }^{2}$ percent focus of infection with respect to control at $20 \mu \mathrm{g} / \mathrm{mL}$ concentration of extracts; ${ }^{3}$ at $200 \mu \mathrm{g} / \mathrm{mL}$ concentration of extracts; ${ }^{4}$ media were added with $104 \mathrm{mM}$ of each magnesium salt.

Another finding suggests that the aqueous extracts of various marine microalgae, namely, Porphyridium cruentum, Chlorella autotrophica, and Ellipsoidon sp., significantly inhibit viral infection hemorrhagic septicemia virus (VHSV) in salmon fish and the African swine fever virus (ASFV) (Table 6). The mechanism underlying this inhibitive effect correlates with the in vitro replication of both viruses in a dose-dependent manner [16]. These findings have made it possible to study the constituent's ability to inhibit RNA and DNA $[109,110]$. They also contribute to the development of broad-spectrum antiviral agents, especially human-related strains [111]. The understanding of human-related an- 
tiviral activity is advanced by findings on cell wall sulfated polysaccharides isolated from Porphyridium sp. The isolated polysaccharides were shown to inhibit HSV-1, HSV-2, and Varicella zoster virus (VZV) without any cytotoxic effects on the Vero cell line [17].

Another study on exopolysaccharides isolated from Porphyridium cruentum also focused on the culture medium influence in the production. A magnesium cation additive (using $\mathrm{MgCl}_{2}$ and $\mathrm{MgSO}_{4}$ ) increased the biomass and exopolysaccharides' yield, leading to slightly better antiviral activity against HSV-1, HSV-2, Vaccinia, and Vesicular stomatitis virus (Table 6). The inhibition of HSV-1 is superior compared to the control medium by $56 \mu \mathrm{g} / \mathrm{mL}$ of $\mathrm{EC}_{50}$ for the control medium and $34-38 \mu \mathrm{g} / \mathrm{mL}$ of $\mathrm{EC}_{50}$ for the magnesiumaltered medium, together with the Vesicular stomatitis virus, which was inhibited by exopolysaccharide by $100 \mu \mathrm{g} / \mathrm{mL}$ of $\mathrm{EC}_{50}$ for the control condition and $20-56 \mu \mathrm{g} / \mathrm{mL}$ of $\mathrm{EC}_{50}$ for the magnesium-altered medium. For HSV-2 and the Vaccinia virus, the inhibition rate improved after adding $\mathrm{MgSO}_{4}$ by $12 \mu \mathrm{g} / \mathrm{mL} \mathrm{EC}_{50}$ for both strains and by $10 \mu \mathrm{g} / \mathrm{mL} \mathrm{EC}_{50}$ after adding $\mathrm{MgCl}_{2}$ addition and applying the control condition for both strains [112].

\section{Outlook and Future Prospects}

Sulfated polysaccharides are well-known for their application in the food and cosmeceuticals industry. These macromolecules are commonly obtained from marine algae and several bacteria, but are not found in terrestrial plants. One survey conducted by Aquino and colleagues revealed that all polysaccharides from marine plants are sulfated [113,114]. This finding is supported by another study on the biosynthesis of sulfated polysaccharides, which found the unshared presence of carbohydrate sulfotransferases and sulfatases on marine algae with terrestrial plants $[115,116]$. This finding on 16 new different sulfatases from Chlamydomonas and an increased number of the class member exhibited a vast diversity of specificity on the substrate and produced compounds to be discovered [115,117].

Herein, the use of carrageenans is especially attractive since most of them have been recognized by the US Food and Drug Administration as "generally recognized as safe" (GRAS) for human consumption (21 CFR 172.620). They also present a low cytotoxicity from other types of sulfated polysaccharides (see Tables 3-5). In addition to their common utilization as a gelling agent in the food industry, their potential broad biological activities have attracted much attention for producing high-quality products for medical treatments. Particularly, the COVID-19 outbreak and emerging variants of the SARS-CoV-2 virus have highlighted the high probability of the emergence or re-emergence of viral infections. They have also tested our readiness to fight against them (and future unknown pathogens) by exploring the potency of antiviral agents from natural sources, including algal-based sulfated polysaccharides.

According to various studies, carrageenan has remarkable potential to be used as an in vitro and in vivo antiviral agent, owing to its wide range of antiviral activities, followed by its relative, fucoidan. Despite the lower amount of attention given to fucoidan, the sulfated polysaccharides could still become antiviral agents. On the other hand, other sulfated polysaccharides have been understudied, providing an opportunity for future researchers.

One research direction that could be followed is the purification of isolated sulfated polysaccharides. The continued study on fucoidan isolated from Adenocystis utricularis has shown that further precipitation using cetrimide improves antiviral agents' activities against HSV-1 and HSV-2 by $0.28 \mu \mathrm{g} / \mathrm{mL}$ and $0.52 \mu \mathrm{g} / \mathrm{mL}$ of $\mathrm{IC}_{50}$, respectively. The fractionated fucoidan has distinctive features, remarked by the uniform constituent of galactofucan [94]. This finding indicates that contaminants or impurities in the fraction interfere with its antiviral capabilities. Along with the interference of antiviral capabilities, the information on the composition determines which component of the complex sulfated polysaccharides holds the potency and indicates the probability of discovering a new synergistic effect between the various composition percentages of different constituents.

Post-isolation processing could also improve antiviral activities. The study of the oligosaccharide of $k$-carrageenan has revealed its effective inhibition of influenza A H1N1 virus replication. A unique mechanism of action was also observed by a derivative of 
K-carrageenan, as it cannot bind to the cell surface of Madin-Darby canine kidney (MDCK) cells, unlike other sulfated polysaccharides. Fortunately, this phenomenon is backed up by the ability to enter the MDCK cell and to subsequently inhibit mRNA and protein expression after the internalization stage of the virus. Not only the ability to inhibit virus replication, but also the study on oligosaccharide of $\mathrm{k}$-carrageenan, indicate that oligosaccharide with a high molecular weight does not inhibit influenza A H1N1 virus replication at a high rate. The relationship between antiviral activity and the molecular weight might be correlated with water solubility and a cell-penetrating ability $[118,119]$. The proposed strategy to use a higher molecular weight is also supported by recent studies conducted by Kwon and colleagues, who showed that a higher molecular weight is related to a higher affinity between fucoidan and the S-protein of SARS-CoV-2. In an in silico study, a higher molecular weight ligand formed tighter binding to the angiotensin-converting enzyme 2 (ACE2) receptor (which is commonly infected by SARS-CoV-2) [120].

Furthermore, the post-isolation treatment of sulfated polysaccharides might be proposed towards their sulfation degree. A previous study suggests that the desulfation of heparan sulfate, which provides $3-\mathrm{OH}$ octasaccharide, inhibits only $50 \%$ of viral entry compared to the same concentration of 3-O-sulfated octasaccharide, which completely inhibits viral entry. This study also showed that 3-O-sulfated octasaccharide can block membrane fusion by saturating the HSV-1 envelope protein $\mathrm{gD}$ in a specific way. This specificity also pointed to the possibility of tuning the sulfation degree of oligosaccharide modification to obtain a specific viral infection inhibitor [121]. The tuning of the sulfation degree can start with comparing commonly isolated carrageenans, which indicates the appropriate degree of sulfation. The sulfate group attached to l-carrageenan lies between mono-sulfated $\mathrm{k}$-carrageenan and tri-sulfated $\lambda$-carrageenan, which shows superior activity against viral infection.

In addition to the versatile compounds of the purification and post-processing of naturally available sulfated polysaccharides, they also exhibit the ability to interfere with further modification with metals. Interestingly, in 2011, Venkatpurwar and colleagues demonstrated that porphyran can be utilized in the synthesis of gold nanoparticles. The synthesized gold nanoparticles were then loaded with doxorubicin to tune drug release behavior. Furthermore, the doxorubicin-loaded gold nanoparticles enhanced the drug's cytotoxicity against the human glioma cell line compared to doxorubicin alone. This enhancement might correlate with the increased doxorubicin internalization, which is aided by nanoparticles and their endocytosis ability. Meanwhile, native doxorubicin relies solely on a passive diffusion mechanism [122]. Similar to porphyran, Manivasagan and colleagues utilized a sulfated polysaccharide, namely, fucoidan, to synthesize a stable gold nanoparticle, which was further utilized as a doxorubicin vehicle. The vehicle inhibited the MDA-MB-231 cell line by $5 \mu \mathrm{g} / \mathrm{mL}$ of IC $_{50}$ compared with native doxorubicin by $15 \mu \mathrm{g} / \mathrm{mL}$ [123]. Another finding suggests that fucoidan-gold nanoparticles alone initiate a decrease in cell viability similar to that resulting from cyclophosphamide, a chemotherapy agent. The observed cell viability is at less than $50 \%$ at a $25 \mu \mathrm{g}$ concentration, both for fucoidan-gold nanoparticles and cyclophosphamide [124]. Meanwhile, the antioxidative capability of the sulfated polysaccharide-iron complex is superior to that of native sulfated polysaccharides [125]. The sulfated polysaccharide could also increase antibacterial activity by using it as a platform for zinc complexion [126] while providing minimal attention to the relationship of the metal modification of sulfated polysaccharides in antiviral activities.

A few features of the metal modification of sulfated polysaccharides still need to be addressed:

1. The encapsulation amount, which correlates with the efficacy concentration;

2. Consideration of the drug preparation (e.g., injections, solids, or transdermal application);

3. Their preservation capabilities, alongside stabilities both before and after uptake;

4. The impact of the bioavailability of the released drug on systemic circulation;

5. The possibility of controlled released tuning in antiviral delivering agents [127]. 
The superiority of fucoidan, porphyran, and other sulfated polysaccharides suggests that the backbone of sulfated polysaccharides can interfere with membrane fusion and the performance of the delivery mechanism. An evaluation of slight modifications to the known delivering vehicle on their degree of sulfation, molecular weight, and similarity with the successor path of $\mathrm{l}$-carrageenan could provide potential antiviral candidates and indicates the specifications needed to overcome viral infections. Owing to their embedded antiviral activities and antioxidative properties, sulfated polysaccharides possess great potential as antiviral agents and delivery vehicles. This potential, combined with the stability exhibited by sulfated polysaccharide nanoparticles and their ability to be controlled within the drug release mechanism, further supports their candidacy as therapeutic agents despite the fact that their study is limited regarding the specific relationship. However, a multidisciplinary approach still needs to be integrated into the study on obtaining, processing, and utilizing sulfated polysaccharides. The developed industry on obtaining sulfated polysaccharides may be used as a benchmark to further utilize sulfated polysaccharides as antiviral agents or delivery vehicles for antiviral prevention and treatment.

Author Contributions: Conceptualization, J.A.P., S.P.A., E.N.Z., A.B., P.A. and M.Y.P.; resources, J.A.P., S.P.A., A.B., E.N.Z., M.Y.P. and S.I.R.; writing—original draft preparation, J.A.P., S.P.A., M.Y.P. and A.B.; writing-review and editing, E.N.Z., A.B., P.A., S.I.R. and M.Y.P.; visualization, J.A.P., S.P.A. and S.I.R.; supervision, E.N.Z., A.B., P.A. and M.Y.P.; project administration, M.Y.P. and E.N.Z. All authors have read and agreed to the published version of the manuscript.

Funding: This research was funded by the Ministry of Education, Culture, Research, and Technology through Basic Research Grant 752/UN4.22/PT.01.3.2021 2021 and by the Indonesian Institute of Sciences through DIPA 2021 Research Fund B-10405/IPH/HK.01.03/XI/2020.

Institutional Review Board Statement: Not applicable.

Informed Consent Statement: Not applicable.

Data Availability Statement: Not applicable.

Acknowledgments: We would like to thank the head of the Research Center for Biotechnology, Life Sciences Research Organization, National Research and Innovation Agency (BRIN), as well as the research and administration staff members, for their support. E.N.Z. thanks the Faculty of Marine Sciences and Fisheries of the University of Hasanuddin for its logistical support.

Conflicts of Interest: The authors declare no conflict of interest.

\section{References}

1. World Health Organization. WHO Coronavirus Disease 2019 Situation Report 51-11th March 2020. WHO Bull. 2020, $2019,2633$.

2. Zhu, N.; Zhang, D.; Wang, W.; Li, X.; Yang, B.; Song, J.; Zhao, X.; Huang, B.; Shi, W.; Lu, R.; et al. A Novel Coronavirus from Patients with Pneumonia in China, 2019. N. Engl. J. Med. 2020, 382, 727-733. [CrossRef] [PubMed]

3. Cohen, J.; Kupferschmidt, K. Countries test tactics in "war" against COVID-19. Science 2020, 367, 1287-1288. [CrossRef] [PubMed]

4. Leung, K.; Shum, M.H.H.; Leung, G.M.; Lam, T.T.Y.; Wu, J.T. Early transmissibility assessment of the N501Y mutant strains of SARS-CoV-2 in the United Kingdom, October to November 2020. Eurosurveillance 2020, 26, 2002106. [CrossRef] [PubMed]

5. Sanches, P.R.S.; Charlie-Silva, I.; Braz, H.L.B.; Bittar, C.; Freitas Calmon, M.; Rahal, P.; Cilli, E.M. Recent advances in SARS-CoV-2 Spike protein and RBD mutations comparison between new variants Alpha (B.1.1.7, United Kingdom), Beta (B.1.351, South Africa), Gamma (P.1, Brazil) and Delta (B.1.617.2, India). J. Virus Erad. 2021, 7, 100054. [CrossRef]

6. Burki, T. COVID-19 and diabetes in Africa: A lethal combination. Lancet Diabetes Endocrinol. 2021, 10, 23. [CrossRef]

7. Tregoning, J.S.; Flight, K.E.; Higham, S.L.; Wang, Z.; Pierce, B.F. Progress of the COVID-19 vaccine effort: Viruses, vaccines and variants versus efficacy, effectiveness and escape. Nat. Rev. Immunol. 2021, 21, 626-636. [CrossRef]

8. Bandyopadhyay, S.S.; Navid, M.H.; Ghosh, T.; Schnitzler, P.; Ray, B. Structural features and in vitro antiviral activities of sulfated polysaccharides from Sphacelaria indica. Phytochemistry 2011, 72, 276-283. [CrossRef]

9. Karmakar, P.; Alberto, C.; Beatriz, E.; Ghosh, T.; Ray, B. Polysaccharides from Padina tetrastromatica: Structural features, chemical modification and antiviral activity. Carbohydr. Polym. 2010, 80, 513-520. [CrossRef]

10. Pujol, C.A.; Ray, S.; Ray, B.; Damonte, E.B. Antiviral activity against dengue virus of diverse classes of algal sulfated polysaccharides. Int. J. Biol. Macromol. 2012, 51, 412-416. [CrossRef]

11. Grassauer, A.; Weinmuellner, R.; Meier, C.; Pretsch, A.; Prieschl-Grassauer, E.; Unger, H. Iota-Carrageenan is a potent inhibitor of rhinovirus infection. Virol. J. 2008, 5, 5-7. [CrossRef] [PubMed] 
12. Wang, W.; Wu, J.; Zhang, X.; Hao, C.; Zhao, X.; Jiao, G.; Shan, X.; Tai, W.; Yu, G. Inhibition of influenza A virus infection by fucoidan targeting viral neuraminidase and cellular EGFR pathway. Sci. Rep. 2017, 7, 1-14. [CrossRef] [PubMed]

13. Muto, S.; Niimura, K.; Oohara, M.; Oguchi, Y.; Matsunaga, K.; Hirose, K.; Kakuchi, J.; Sugita, N.; Furusho, T.; Yoshikumi, C.; et al. Polysaccharides from Marine Algae and Antiviral Drugs Containing the Same as Active Ingredient. U.S. Patent 5,089,481 A, 18 February 1992.

14. Santos, S.; Ferreira, T.; Almeida, J.; Pires, M.J.; Colaço, A.; Lemos, S.; Da Costa, R.M.G.; Medeiros, R.; Bastos, M.M.S.M.; Neuparth, M.J.; et al. Dietary supplementation with the red seaweed porphyra umbilicalis protects against DNA damage and pre-malignant dysplastic skin lesions in HPV-transgenic mice. Mar. Drugs 2019, 17, 615. [CrossRef] [PubMed]

15. Hasui, M.; Matsuda, M.; Okutani, K.; Shigeta, S. In vitro antiviral activities of sulfated polysaccharides from a marine microalga (Cochlodinium polykrikoides) against human immunodeficiency virus and other enveloped viruses. Int. J. Biol. Macromol. 1995, 17, 293-297. [CrossRef]

16. Fabregas, J.; García, D.; Fernandez-Alonso, M.; Rocha, A.I.; Gómez-Puertas, P.; Escribano, J.M.; Otero, A.; Coll, J.M. In vitro inhibition of the replication of haemorrhagic septicaemia virus (VHSV) and African swine fever virus (ASFV) by extracts from marine microalgae. Antivir. Res. 1999, 44, 67-73. [CrossRef]

17. Huleihel, M.; Ishanu, V.; Tal, J.; Arad, S. Antiviral effect of red microalgal polysaccharides on Herpes simplex and Varicella zoster viruses. J. Appl. Phycol. 2001, 13, 127-134. [CrossRef]

18. Yim, S.K.; Kim, K.; Kim, I.; Chun, S.H.; Oh, T.H.; Kim, J.U.; Kim, J.; Jung, W.; Moon, H.; Ku, B.; et al. Inhibition of sars-cov-2 virus entry by the crude polysaccharides of seaweeds and abalone viscera in vitro. Mar. Drugs 2021, 19, 219. [CrossRef]

19. Figueroa, J.M.; Lombardo, M.E.; Dogliotti, A.; Flynn, L.P.; Giugliano, R.; Simonelli, G.; Valentini, R.; Ramos, A.; Romano, P.; Marcote, M.; et al. Efficacy of a Nasal Spray Containing Iota-Carrageenan in the Postexposure Prophylaxis of COVID-19 in Hospital Personnel Dedicated to Patients Care with COVID-19 Disease. Int. J. Gen. Med. 2021, 14, 6277-6286. [CrossRef]

20. Lauritano, C.; Andersen, J.H.; Hansen, E.; Albrigtsen, M.; Escalera, L.; Esposito, F.; Helland, K.; Hanssen, K.; Romano, G.; Ianora, A. Bioactivity screening of microalgae for antioxidant, anti-inflammatory, anticancer, anti-diabetes, and antibacterial activities. Front. Mar. Sci. 2016, 3, 1-2. [CrossRef]

21. Pangestuti, R.; Kim, S.K. Biological Activities of Carrageenan, 1st ed.; Elsevier Inc.: Amsterdam, The Netherlands, 2014; Volume 72, ISBN 9780128002698.

22. Ciancia, M.; Fernández, P.V.; Leliaert, F. Diversity of Sulfated Polysaccharides From Cell Walls of Coenocytic Green Algae and Their Structural Relationships in View of Green Algal Evolution. Front. Plant Sci. 2020, 11, 1-15. [CrossRef]

23. Muthukumar, J.; Chidambaram, R.; Sukumaran, S. Sulfated polysaccharides and its commercial applications in food industries-A review. J. Food Sci. Technol. 2021, 58, 2453-2466. [CrossRef] [PubMed]

24. El Gamal, A.A. Biological Importance of Marine Algae. In Handbook of Marine Macroalgae: Biotechnology and Applied Phycology; John Wiley \& Sons: Chichester, UK, 2011; pp. 1-35. [CrossRef]

25. Kerrison, P.D. Algae as Crops Seaweed, 2nd ed.; Elsevier: Amsterdam, The Netherlands, 2016; Volume 3, ISBN 9780123948083.

26. Wang, J.; Wang, D.; Zhang, Y.; Dong, J. Synthesis and Biopharmaceutical Applications of Sugar-Based Polymers: New Advances and Future Prospects. ACS Biomater. Sci. Eng. 2021, 7, 963-982. [CrossRef] [PubMed]

27. Domínguez, H. Algae as a source of biologically active ingredients for the formulation of functional foods and nutraceuticals. In Functional Ingredients from Algae Foods Nutraceuticals; Woodhead Publishing: Sawston, UK, 2013; pp. 1-19. [CrossRef]

28. Dominguez, H.; Loret, E.P. Ulva lactuca, A Source of Troubles and Potential Riches. Mar. Drugs 2019, 17, 357. [CrossRef] [PubMed]

29. Cunha, L.; Grenha, A. Sulfated seaweed polysaccharides as multifunctional materials in drug delivery applications. Mar. Drugs 2016, 14, 42. [CrossRef]

30. Ahmed, A.B.A.; Adel, M.; Karimi, P.; Peidayesh, M. Pharmaceutical, Cosmeceutical, and Traditional Applications of Marine Carbohydrates, 1st ed.; Elsevier Inc.: Amsterdam, The Netherlands, 2014; Volume 73, ISBN 9780128002681.

31. Thakur, V.; Lu, J.; Roscilli, G.; Aurisicchio, L.; Cappelletti, M.; Pavoni, E.; White, W.L.; Bedogni, B. The natural compound fucoidan from New Zealand Undaria pinnatifida synergizes with the ERBB inhibitor lapatinib enhancing melanoma growth inhibition. Oncotarget 2017, 8, 17887-17896. [CrossRef] [PubMed]

32. Hong, S.W.; Jung, K.H.; Lee, H.S.; Zheng, H.M.; Choi, M.J.; Lee, C.; Hong, S.S. Suppression by fucoidan of liver fibrogenesis via the TGF- $\beta$ /smad pathway in protecting against oxidative stress. Biosci. Biotechnol. Biochem. 2011, 75, 833-840. [CrossRef]

33. Berri, M.; Olivier, M.; Holbert, S.; Dupont, J.; Demais, H.; Le Goff, M.; Collen, P.N. Ulvan from Ulva armoricana (Chlorophyta) activates the PI3K/Akt signalling pathway via TLR4 to induce intestinal cytokine production. Algal Res. 2017, $28,39-47$. [CrossRef]

34. Li, W.; Jiang, N.; Li, B.; Wan, M.; Chang, X.; Liu, H.; Zhang, L.; Yin, S.; Qi, H.; Liu, S. Antioxidant activity of purified ulvan in hyperlipidemic mice. Int. J. Biol. Macromol. 2018, 113, 971-975. [CrossRef]

35. Albuquerque, J.C.S.; Araújo, M.L.H.; Rocha, M.V.P.; de Souza, B.W.S.; de Castro, G.M.C.; Cordeiro, E.M.S.; de Suosa Silva, J.; Benevides, N.M.B. Acid hydrolysis conditions for the production of fine chemicals from Gracilaria birdiae alga biomass. Algal Res. 2021, 53, 102139. [CrossRef]

36. Fayaz, M.; Namitha, K.K.; Murthy, K.N.C.; Swamy, M.M.; Sarada, R.; Khanam, S.; Subbarao, P.V.; Ravishankar, G.A. Chemical composition, iron bioavailability, and antioxidant activity of Kappaphycus alvarezzi (Doty). J. Agric. Food Chem. 2005, 53, 792-797. [CrossRef] 
37. Yang, Y.; Zhang, M.; Alalawy, A.I.; Almutairi, F.M.; Al-Duais, M.A.; Wang, J.; Salama, E.-S. Identification and characterization of marine seaweeds for biocompounds production. Environ. Technol. Innov. 2021, 24, 101848. [CrossRef]

38. Yu, G.; Zhang, Q.; Wang, Y.; Yang, Q.; Yu, H.; Li, H.; Chen, J.; Fu, L. Sulfated polysaccharides from red seaweed Gelidium amansii: Structural characteristics, antioxidant and anti-glycation properties, and development of bioactive films. Food Hydrocoll. 2021, 119, 106820. [CrossRef]

39. Caballero, E.; Flores, A.; Olivares, A. Sustainable exploitation of macroalgae species from Chilean coast: Characterization and food applications. Algal Res. 2021, 57, 102349. [CrossRef]

40. Lorenzo, J.M.; Agregán, R.; Munekata, P.E.S.; Franco, D.; Carballo, J.; Şahin, S.; Lacomba, R.; Barba, F.J. Proximate composition and nutritional value of three macroalgae: Ascophyllum nodosum, Fucus vesiculosus and Bifurcaria bifurcata. Mar. Drugs 2017, 15, 360. [CrossRef] [PubMed]

41. Kumar, M.; Gupta, V.; Kumari, P.; Reddy, C.R.K.; Jha, B. Assessment of nutrient composition and antioxidant potential of Caulerpaceae seaweeds. J. Food Compos. Anal. 2011, 24, 270-278. [CrossRef]

42. Bahari, A.; Moelants, K.; Wallecan, J.; Mangiante, G.; Mazoyer, J.; Hendrickx, M.; Grauwet, T. Understanding the effect of time, temperature and salts on carrageenan extraction from Chondrus crispus. Algal Res. 2021, 58, 102371. [CrossRef]

43. Mansilla, A.; Ávila, M. Using Macrocystis pyrifera (L.) C. Agardh from southern Chile as a source of applied biological compounds. Rev. Bras. Farmacogn. 2011, 21, 262-267. [CrossRef]

44. Garcia-Vaquero, M.; Rajauria, G.; Miranda, M.; Sweeney, T.; Lopez-Alonso, M.; O’Doherty, J. Seasonal Variation of the Proximate Composition, Mineral Content, Fatty Acid Profiles and Other Phytochemical Constituents of Selected Brown Macroalgae. Mar. Drugs 2021, 19, 204. [CrossRef]

45. Ethier, S.; Woisard, K.; Vaughan, D.; Wen, Z. Continuous culture of the microalgae Schizochytrium limacinum on biodiesel-derived crude glycerol for producing docosahexaenoic acid. Bioresour. Technol. 2011, 102, 88-93. [CrossRef]

46. Bongiorno, T.; Foglio, L.; Proietti, L.; Vasconi, M.; Lopez, A.; Pizzera, A.; Carminati, D.; Tava, A.; Vizcaíno, A.J.; Alarcón, F.J.; et al. Microalgae from Biorefinery as Potential Protein Source for Siberian Sturgeon (A. baerii) Aquafeed. Sustainability 2020, $12,8779$. [CrossRef]

47. Grossmann, L.; Hinrichs, J.; Weiss, J. Cultivation and downstream processing of microalgae and cyanobacteria to generate protein-based technofunctional food ingredients. Crit. Rev. Food Sci. Nutr. 2020, 60, 2961-2989. [CrossRef] [PubMed]

48. Khatoon, H.; Abdu Rahman, N.; Banerjee, S.; Harun, N.; Suleiman, S.S.; Zakaria, N.H.; Lananan, F.; Abdul Hamid, S.H.; Endut, A.; Abdu, N.; et al. Effects of different salinities and $\mathrm{pH}$ on the growth and proximate composition of Nannochloropsis sp. and Tetraselmis sp. isolated from South China Sea cultured under control and natural condition. Int. Biodeterior. Biodegrad. 2014, 95, 11-18. [CrossRef]

49. Menegol, T.; Diprat, A.B.; Rodrigues, E.; Rech, R. Effect of temperature and nitrogen concentration on biomass composition of Heterochlorella luteoviridis. Food Sci. Technol. 2017, 37, 28-37. [CrossRef]

50. Kumaran, J.; Poulose, S.; Joseph, V.; Bright Singh, I.S. Enhanced biomass production and proximate composition of marine microalga Nannochloropsis oceanica by optimization of medium composition and culture conditions using response surface methodology. Anim. Feed Sci. Technol. 2021, 271, 114761. [CrossRef]

51. Abu-Ghosh, S.; Dubinsky, Z.; Verdelho, V.; Iluz, D. Unconventional high-value products from microalgae: A review. Bioresour. Technol. 2021, 329, 124895. [CrossRef]

52. Di Lena, G.; Casini, I.; Lucarini, M.; Sanchez del Pulgar, J.; Aguzzi, A.; Caproni, R.; Gabrielli, P.; Lombardi-Boccia, G. Chemical characterization and nutritional evaluation of microalgal biomass from large-scale production: A comparative study of five species. Eur. Food Res. Technol. 2020, 246, 323-332. [CrossRef]

53. Assunção, M.F.G.; Varejão, J.M.T.B.; Santos, L.M.A. Nutritional characterization of the microalga Ruttnera lamellosa compared to Porphyridium purpureum. Algal Res. 2017, 26, 8-14. [CrossRef]

54. Alagawany, M.; Taha, A.E.; Noreldin, A.; El-Tarabily, K.A.; Abd El-Hack, M.E. Nutritional applications of species of Spirulina and Chlorella in farmed fish: A review. Aquaculture 2021, 542, 736841. [CrossRef]

55. Grossmann, L.; Ebert, S.; Hinrichs, J.; Weiss, J. Effect of precipitation, lyophilization, and organic solvent extraction on preparation of protein-rich powders from the microalgae Chlorella protothecoides. Algal Res. 2018, 29, 266-276. [CrossRef]

56. Estevez, J.M.; Ciancia, M.; Cerezo, A.S. The system of sulfated galactans from the red seaweed Gymnogongrus torulosus (Phyllophoraceae, Rhodophyta): Location and structural analysis. Carbohydr. Polym. 2008, 73, 594-605. [CrossRef]

57. Perez Recalde, M.; Canelón, D.J.; Compagnone, R.S.; Matulewicz, M.C.; Cerezo, A.S.; Ciancia, M. Carrageenan and agaran structures from the red seaweed Gymnogongrus tenuis. Carbohydr. Polym. 2016, 136, 1370-1378. [CrossRef] [PubMed]

58. Estevez, J.M.; Ciancia, M.; Cerezo, A.S. The system of galactans of the red seaweed, Kappaphycus alvarezii, with emphasis on its minor constituents. Carbohydr. Res. 2004, 339, 2575-2592. [CrossRef] [PubMed]

59. Qureshi, D.; Nayak, S.K.; Maji, S.; Kim, D.; Banerjee, I.; Pal, K. Carrageenan: A Wonder Polymer from Marine Algae for Potential Drug Delivery Applications. Curr. Pharm. Des. 2019, 25, 1172-1186. [CrossRef] [PubMed]

60. Li, L.; Ni, R.; Shao, Y.; Mao, S. Carrageenan and its applications in drug delivery. Carbohydr. Polym. 2014, 103, 1-11. [CrossRef]

61. Kariduraganavar, M.Y.; Kittur, A.A.; Kamble, R.R. Polymer Synthesis and Processing, 1st ed.; Elsevier Inc.: Amsterdam, The Netherlands, 2014; ISBN 9780123969835

62. Campo, V.L.; Kawano, D.F.; da Silva, D.B.; Carvalho, I. Carrageenans: Biological properties, chemical modifications and structural analysis-A review. Carbohydr. Polym. 2009, 77, 167-180. [CrossRef] 
63. Pereira, L. Seaweeds as Source of Bioactive Substances and Skin Care Therapy-Cosmeceuticals, Algotheraphy, and Thalassotherapy. Cosmetics 2018, 5, 68. [CrossRef]

64. Alba, K.; Kontogiorgos, V. Seaweed Polysaccharides (Agar, Alginate Carrageenan); Elsevier: Amsterdam, The Netherlands, 2018; ISBN 9780128140451.

65. Imeson, A.P. Carrageenan and furcellaran. In Handbook of Hydrocolloids; Elsevier: Amsterdam, The Netherlands, 2009; pp. 164-185. ISBN 9781845695873

66. García-Poza, S.; Leandro, A.; Cotas, C.; Cotas, J.; Marques, J.C.; Pereira, L.; Gonçalves, A.M.M. The Evolution Road of Seaweed Aquaculture: Cultivation Technologies and the Industry 4.0. Int. J. Environ. Res. Public Health 2020, 17, 6528. [CrossRef]

67. Zúñiga, E.A.; Matsuhiro, B.; Mejías, E. Preparation of a low-molecular weight fraction by free radical depolymerization of the sulfated galactan from Schizymenia binderi (Gigartinales, Rhodophyta) and its anticoagulant activity. Carbohydr. Polym. 2006, 66, 208-215. [CrossRef]

68. Stanley, N.F. Agars. In Food Polysaccharides and Their Applications; CRC Press: Boca Raton, FL, USA, 2016; pp. $231-252$.

69. Ale, M.T.; Meyer, A.S. Fucoidans from brown seaweeds: An update on structures, extraction techniques and use of enzymes as tools for structural elucidation. RSC Adv. 2013, 3, 8131-8141. [CrossRef]

70. Oliveira, C.; Neves, N.M.; Reis, R.L.; Martins, A.; Silva, T.H. A review on fucoidan antitumor strategies: From a biological active agent to a structural component of fucoidan-based systems. Carbohydr. Polym. 2020, 239, 116131. [CrossRef]

71. Isnansetyo, A.; Lutfia, F.N.L.; Nursid, M.; Trijoko, T.; Susidarti, R.A. Cytotoxicity of fucoidan from three tropical brown algae against breast and colon cancer cell lines. Pharmacogn. J. 2017, 9, 14-20. [CrossRef]

72. Zayed, A.; Dienemann, C.; Giese, C.; Krämer, R.; Ulber, R. An immobilized perylene diimide derivative for fucoidan purification from a crude brown algae extract. Process Biochem. 2018, 65, 233-238. [CrossRef]

73. Zhang, Q.; Qi, H.; Zhao, T.; Deslandes, E.; Ismaeli, N.M.; Molloy, F.; Critchley, A.T. Chemical characteristics of a polysaccharide from Porphyra capensis (Rhodophyta). Carbohydr. Res. 2005, 340, 2447-2450. [CrossRef]

74. Qiu, Y.; Jiang, H.; Fu, L.; Ci, F.; Mao, X. Porphyran and oligo-porphyran originating from red algae Porphyra: Preparation, biological activities, and potential applications. Food Chem. 2021, 349, 129209. [CrossRef] [PubMed]

75. Isaka, S.; Cho, K.; Nakazono, S.; Abu, R.; Ueno, M.; Kim, D.; Oda, T. Antioxidant and anti-inflammatory activities of porphyran isolated from discolored nori (Porphyra yezoensis). Int. J. Biol. Macromol. 2015, 74, 68-75. [CrossRef] [PubMed]

76. Chen, Y.-y.; Xue, Y.-t. Optimization of microwave assisted extraction, chemical characterization and antitumor activities of polysaccharides from porphyra haitanensis. Carbohydr. Polym. 2019, 206, 179-186. [CrossRef] [PubMed]

77. Lahaye, M.; Robic, A. Structure and function properties of Ulvan, a polysaccharide from green seaweeds. Biomacromolecules 2007, 8, 1765-1774. [CrossRef] [PubMed]

78. Kidgell, J.T.; Magnusson, M.; de Nys, R.; Glasson, C.R.K. Ulvan: A systematic review of extraction, composition and function Algal Res. 2019, 39, 101422. [CrossRef]

79. Glasson, C.R.K.; Sims, I.M.; Carnachan, S.M.; de Nys, R.; Magnusson, M. A cascading biorefinery process targeting sulfated polysaccharides (ulvan) from Ulva ohnoi. Algal Res. 2017, 27, 383-391. [CrossRef]

80. Pereira, S.; Zille, A.; Micheletti, E.; Moradas-Ferreira, P.; De Philippis, R.; Tamagnini, P. Complexity of cyanobacterial exopolysaccharides: Composition, structures, inducing factors and putative genes involved in their biosynthesis and assembly. FEMS Microbiol. Rev. 2009, 33, 917-941. [CrossRef]

81. Mancuso Nichols, C.A.; Guezennec, J.; Bowman, J.P. Bacterial exopolysaccharides from extreme marine environments with special consideration of the Southern Ocean, sea ice, and deep-sea hydrothermal vents: A review. Mar. Biotechnol. 2005, 7, 253-271. [CrossRef] [PubMed]

82. Gaignard, C.; Laroche, C.; Pierre, G.; Dubessay, P.; Delattre, C.; Gardarin, C.; Gourvil, P.; Probert, I.; Dubuffet, A.; Michaud, P. Screening of marine microalgae: Investigation of new exopolysaccharide producers. Algal Res. 2019, 44, 101711. [CrossRef]

83. Kim, K.J.; Lee, O.H.; Lee, B.Y. Fucoidan, a sulfated polysaccharide, inhibits adipogenesis through the mitogen-activated protein kinase pathway in 3T3-L1 preadipocytes. Life Sci. 2010, 86, 791-797. [CrossRef] [PubMed]

84. Andri Frediansyah, S.S. The antiviral activity of iota-, kappa-, and lambda-carrageenan against COVID-19: A critical review. Clin. Epidemiol. Glob. Health 2021, 12, 100826. [CrossRef]

85. Jabeen, M.; Dutot, M.; Fagon, R.; Verrier, B.; Monge, C. Seaweed sulfated polysaccharides against respiratory viral infections Pharmaceutics 2021, 13, 733. [CrossRef]

86. Reynolds, D.; Huesemann, M.; Edmundson, S.; Sims, A.; Hurst, B.; Cady, S.; Beirne, N.; Freeman, J.; Berger, A.; Gao, S. Viral inhibitors derived from macroalgae, microalgae, and cyanobacteria: A review of antiviral potential throughout pathogenesis. Algal Res. 2021, 57, 102331. [CrossRef]

87. Adalja, A.; Inglesby, T. Broad-Spectrum Antiviral Agents: A Crucial Pandemic Tool. Expert Rev. Anti-infect. Ther. 2019, 17, 467-470 [CrossRef]

88. Morokutti-Kurz, M.; Fröba, M.; Graf, P.; Große, M.; Grassauer, A.; Auth, J.; Schubert, U.; Prieschl-Grassauer, E. Iota-carrageenan neutralizes SARS-CoV-2 and inhibits viral replication in vitro. PLoS ONE 2021, 16, e0237480. [CrossRef]

89. Song, S.; Peng, H.; Wang, Q.; Liu, Z.; Dong, X.; Wen, C.; Ai, C.; Zhang, Y.; Wang, Z.; Zhu, B. Inhibitory activities of marine sulfated polysaccharides against SARS-CoV-2. Food Funct. 2020, 11, 7415-7420. [CrossRef]

90. Jang, Y.; Shin, H.; Lee, M.K.; Kwon, O.S.; Shin, J.S.; Kim, Y.-i.; Kim, C.W.; Lee, H.R.; Kim, M. Antiviral activity of lambdacarrageenan against influenza viruses and severe acute respiratory syndrome coronavirus 2. Sci. Rep. 2021, 11, 1-12. [CrossRef] 
91. Hans, N.; Malik, A.; Naik, S. Antiviral activity of sulfated polysaccharides from marine algae and its application in combating COVID-19: Mini review. Bioresour. Technol. Rep. 2021, 13, 100623. [CrossRef] [PubMed]

92. Aguilar-Briseño, J.A.; Cruz-Suarez, L.E.; Sassi, J.F.; Ricque-Marie, D.; Zapata-Benavides, P.; Mendoza-Gamboa, E.; RodríguezPadilla, C.; Trejo-Avila, L.M. Sulphated polysaccharides from Ulva clathrata and Cladosiphon okamuranus seaweeds both inhibit viral attachment/entry and cell-cell fusion, in NDV infection. Mar. Drugs 2015, 13, 697-712. [CrossRef] [PubMed]

93. Jiao, G.; Yu, G.; Zhang, J.; Ewart, H.S. Chemical structures and bioactivities of sulfated polysaccharides from marine algae. Mar. Drugs 2011, 9, 196-233. [CrossRef]

94. Ponce, N.M.A.; Pujol, C.A.; Damonte, E.B.; Flores, M.L.; Stortz, C.A. Fucoidans from the brown seaweed Adenocystis utricularis: Extraction methods, antiviral activity and structural studies. Carbohydr. Res. 2003, 338, 153-165. [CrossRef]

95. Lee, J.-B.; Hayashi, K.; Hashimoto, M.; Nakano, T.; Hayashi, T. Novel Antiviral Fucoidan from Sporophyll of Undaria pinnatifida (Mekabu). Chem. Pharm. Bull. 2004, 52, 1091-1094. [CrossRef] [PubMed]

96. Marks, R.M.; Lu, H.; Sundaresan, R.; Toida, T.; Suzuki, A.; Imanari, T.; Hernáiz, M.J.; Linhardt, R.J. Probing the interaction of dengue virus envelope protein with heparin: Assessment of glycosaminoglycan-derived inhibitors. J. Med. Chem. 2001, 44, 2178-2187. [CrossRef]

97. Lu, W.; Yang, Z.; Chen, J.; Wang, D.; Zhang, Y. Recent advances in antiviral activities and potential mechanisms of sulfated polysaccharides. Carbohydr. Polym. 2021, 272, 118526. [CrossRef]

98. Zhang, H.; Wang, J.Q.; Nie, S.P.; Wang, Y.X.; Cui, S.W.; Xie, M.Y. Sulfated modification, characterization and property of a water-insoluble polysaccharide from Ganoderma atrum. Int. J. Biol. Macromol. 2015, 79, 248-255. [CrossRef]

99. Bao, H.; Choi, W.S.; You, S. Effect of sulfated modification on the molecular characteristics and biological activities of polysaccharides from Hypsizigus marmoreus. Biosci. Biotechnol. Biochem. 2010, 74, 1408-1414. [CrossRef]

100. Helen Fitton, J.; Park, A.Y.; Karpiniec, S.S.; Stringer, D.N. Fucoidan and lung function: Value in viral infection. Mar. Drugs 2021, 19, 4. [CrossRef]

101. Nadeeka Madushani Herath, K.H.I.; Kim, H.J.; Kim, A.; Sook, C.E.; Lee, B.Y.; Jee, Y. The role of fucoidans isolated from the sporophylls of undaria pinnatifida against particulate-matter-induced allergic airway inflammation: Evidence of the attenuation of oxidative stress and inflammatory responses. Molecules 2020, 25, 2869. [CrossRef] [PubMed]

102. Dutot, M.; Grassin-Delyle, S.; Salvator, H.; Brollo, M.; Rat, P.; Fagon, R.; Naline, E.; Devillier, P. A marine-sourced fucoidan solution inhibits Toll-like-receptor-3-induced cytokine release by human bronchial epithelial cells. Int. J. Biol. Macromol. 2019, 130, 429-436. [CrossRef] [PubMed]

103. Duarte, M.E.R.; Noseda, D.G.; Noseda, M.D.; Tulio, S.; Pujol, C.A.; Damonte, E.B. Inhibitory effect of sulfated galactans from the marine alga Bostrychia montagnei on herpes simplex virus replication in vitro. Phytomedicine 2001, 8, 53-58. [CrossRef]

104. Duarte, M.E.R.; Cauduro, J.P.; Noseda, D.G.; Noseda, M.D.; Gonçalves, A.G.; Pujol, C.A.; Damonte, E.B.; Cerezo, A.S. The structure of the agaran sulfate from Acanthophora spicifera (Rhodomelaceae, Ceramiales) and its antiviral activity. Relation between structure and antiviral activity in agarans. Carbohydr. Res. 2004, 339, 335-347. [CrossRef] [PubMed]

105. Hardouin, K.; Bedoux, G.; Burlot, A.S.; Donnay-Moreno, C.; Bergé, J.P.; Nyvall-Collén, P.; Bourgougnon, N. Enzyme-assisted extraction (EAE) for the production of antiviral and antioxidant extracts from the green seaweed Ulva armoricana (Ulvales, Ulvophyceae). Algal Res. 2016, 16, 233-239. [CrossRef]

106. Chiu, Y.H.; Chan, Y.L.; Li, T.L.; Wu, C.J. Inhibition of Japanese Encephalitis Virus Infection by the Sulfated Polysaccharide Extracts from Ulva lactuca. Mar. Biotechnol. 2012, 14, 468-478. [CrossRef] [PubMed]

107. Zhao, T.; Zhang, Q.; Qi, H.; Zhang, H.; Niu, X.; Xu, Z.; Li, Z. Degradation of porphyran from Porphyra haitanensis and the antioxidant activities of the degraded porphyrans with different molecular weight. Int. J. Biol. Macromol. 2006, 38, 45-50. [CrossRef]

108. Li, Y.T.; Huo, Y.F.; Wang, F.; Wang, C.; Zhu, Q.; Wang, Y.B.; Fu, L.L.; Zhou, T. Improved antioxidant and immunomodulatory activities of enzymatically degraded Porphyra haitanensis polysaccharides. J. Food Biochem. 2020, 44, 1-13. [CrossRef]

109. López-Vázquez, C.; Bandín, I.; Panzarin, V.; Toffan, A.; Cuenca, A.; Olesen, N.J.; Dopazo, C.P. Steps of the replication cycle of the viral haemorrhagic septicaemia virus (VHSV) affecting its virulence on fish. Animals 2020, 10, 2264. [CrossRef]

110. Gaudreault, N.N.; Madden, D.W.; Wilson, W.C.; Trujillo, J.D.; Richt, J.A. African Swine Fever Virus: An Emerging DNA Arbovirus. Front. Vet. Sci. 2020, 7, 1-17. [CrossRef]

111. Kleandrova, V.V.; Speck-Planche, A. The urgent need for pan-antiviral agents: From multitarget discovery to multiscale design. Future Med. Chem. 2021, 13, 5-8. [CrossRef] [PubMed]

112. Raposo, M.F.D.J.; De Morais, A.M.M.B.; De Morais, R.M.S.C. Influence of sulphate on the composition and antibacterial and antiviral properties of the exopolysaccharide from Porphyridium cruentum. Life Sci. 2014, 101, 56-63. [CrossRef] [PubMed]

113. Usov, A.I.; Zelinsky, N.D. Chemical Structures of Algal Polysaccharides; Woodhead Publishing Limited: Sawston, UK, 2013; ISBN 9780857095121

114. Aquino, R.S.; Grativol, C.; Mourão, P.A.S. Rising from the sea: Correlations between sulfated polysaccharides and salinity in plants. PLoS ONE 2011, 6, e18862. [CrossRef] [PubMed]

115. Popper, Z.A.; Michel, G.; Hervé, C.; Domozych, D.S.; Willats, W.G.T.; Tuohy, M.G.; Kloareg, B.; Stengel, D.B. Evolution and diversity of plant cell walls: From algae to flowering plants. Annu. Rev. Plant Biol. 2011, 62, 567-590. [CrossRef] [PubMed] 
116. Michel, G.; Tonon, T.; Scornet, D.; Cock, J.M.; Kloareg, B. The cell wall polysaccharide metabolism of the brown alga Ectocarpus siliculosus. Insights into the evolution of extracellular matrix polysaccharides in Eukaryotes. New Phytol. 2010, 188, 82-97. [CrossRef]

117. Merchant, S.S.; Prochnik, S.E.; Vallon, O.; Harris, E.H.; Karpowicz, S.J.; Witman, G.B.; Terry, A.; Salamov, A.; Fritz-Laylin, L.K.; Maréchal-Drouard, L.; et al. The Chlamydomonas Genome Reveals the Evolution of Key Animal and Plant Functions. Science 2007, 318, 245-250. [CrossRef]

118. Hebar, A.; Koller, C.; Seifert, J.M.; Chabicovsky, M.; Bodenteich, A.; Bernkop-Schnürch, A.; Grassauer, A.; Prieschl-Grassauer, E. Non-clinical safety evaluation of intranasal iota-carrageenan. PLoS ONE 2015, 10, e0122911. [CrossRef]

119. Wang, W.; Zhang, P.; Hao, C.; Zhang, X.E.; Cui, Z.Q.; Guan, H.S. In vitro inhibitory effect of carrageenan oligosaccharide on influenza A H1N1 virus. Antivir. Res. 2011, 92, 237-246. [CrossRef]

120. Kwon, P.S.; Oh, H.; Kwon, S.J.; Jin, W.; Zhang, F.; Fraser, K.; Hong, J.J.; Linhardt, R.J.; Dordick, J.S. Sulfated polysaccharides effectively inhibit SARS-CoV-2 in vitro. Cell Discov. 2020, 6, 4-7. [CrossRef]

121. Copeland, R.; Balasubramaniam, A.; Tiwari, V.; Zhang, F.; Bridges, A.; Linhardt, R.J.; Shukla, D.; Liu, J. Using a 3-O-sulfated heparin octasaccharide to inhibit the entry of herpes simplex virus type 1. Biochemistry 2008, 47, 5774-5783. [CrossRef]

122. Venkatpurwar, V.; Shiras, A.; Pokharkar, V. Porphyran capped gold nanoparticles as a novel carrier for delivery of anticancer drug: In vitro cytotoxicity study. Int. J. Pharm. 2011, 409, 314-320. [CrossRef] [PubMed]

123. Manivasagan, P.; Bharathiraja, S.; Bui, N.Q.; Jang, B.; Oh, Y.O.; Lim, I.G.; Oh, J. Doxorubicin-loaded fucoidan capped gold nanoparticles for drug delivery and photoacoustic imaging. Int. J. Biol. Macromol. 2016, 91, 578-588. [CrossRef] [PubMed]

124. Rajeshkumar, S.; Malarkodi, C.; Al Farraj, D.A.; Soliman Elshikh, M.; Mohana Roopan, S. Employing sulphated polysaccharide (fucoidan) as medium for gold nanoparticles preparation and its anticancer study against HepG2 cell lines. Mater. Today Commun. 2021, 26, 101975. [CrossRef]

125. Xian, H.; Wang, P.; Jing, H.; Chen, G.-q.; Cheng, D.-f.; Ji, F.; Song, S.; Zhang, L. Comparative study of components and antioxidative effects between sulfated polysaccharide and its iron complex. Int. J. Biol. Macromol. 2018, 118, 1303-1309. [CrossRef]

126. Netanel Liberman, G.; Ochbaum, G.; Arad, S.; Bitton, R. The sulfated polysaccharide from a marine red microalga as a platform for the incorporation of zinc ions. Carbohydr. Polym. 2016, 152, 658-664. [CrossRef] [PubMed]

127. Delshadi, R.; Bahrami, A.; McClements, D.J.; Moore, M.D.; Williams, L. Development of nanoparticle-delivery systems for antiviral agents: A review. J. Control. Release 2021, 331, 30-44. [CrossRef] [PubMed] 